\title{
The Upper Aptian to Lower Albian syn-rift carbonate succession of the southern Maestrat Basin (Spain): Facies architecture and fault- controlled stratabound dolostones
}

\author{
J.D. Martín-Martín ${ }^{\text {a,b,i, }, \text {, E. Gomez-Rivas }}{ }^{\text {c, d,i }}$, T. Bover-Arnal ${ }^{\mathrm{e}}$, A. Travé ${ }^{\mathrm{a}, \mathrm{i}}$, R. Salas ${ }^{\mathrm{a}, \mathrm{i}}$, J.A. Moreno-Bedmar ${ }^{\mathrm{f}}$, \\ S. Tomás ${ }^{g}$, M. Corbella ${ }^{\mathrm{d}, \mathrm{i}}$, A. Teixell ${ }^{\mathrm{d}, \mathrm{i}}$, J. Vergés ${ }^{\mathrm{b}}$, S.L. Stafford ${ }^{\mathrm{h}, \mathrm{i}}$ \\ ${ }^{a}$ Departament de Petrologia, Geoquímica i Prospecció Geològica, Universitat de Barcelona, 08028 Barcelona, Spain \\ ${ }^{\mathrm{b}}$ Group of Dynamics of the Lithosphere, Institute of Earth Sciences Jaume Almera (ICTJA-CSIC), 08028 Barcelona, Spain \\ ${ }^{\mathrm{c}}$ Department of Geosciences, Eberhard Karls University Tübingen, Wilhelmstr. 56, 72074 Tübingen, Germany \\ d Departament de Geologia, Universitat Autònoma de Barcelona, 08193 Bellaterra (Cerdanyola del Vallès), Spain \\ e Département de Géosciences, Université de Fribourg, Chemin du Musée 6, 1700 Fribourg, Switzerland \\ f Instituto de Geología, Universidad Nacional Autónoma de México, Ciudad Universitaria, Coyoacán, 04510 México D.F., Mexico \\ ${ }^{\mathrm{g}}$ Institut für Erd- und Umweltwissenschaften, Potsdam University, Potsdam-Golm, Germany \\ ${ }^{\mathrm{h}}$ ExxonMobil Upstream Research Company, P.O. Box 2189, Houston, TX 77584-2189, USA \\ ${ }^{\mathrm{i}}$ ExxonMobil (FC) ${ }^{2}$ Alliance_Fundamental Controls on Flow in Carbonates, USA
}

\begin{abstract}
Syn-rift shallow-marine carbonates of Late Aptian to Early Albian age in the southern Maestrat Basin (E Spain) register the thickest Aptian sedimentary record of the basin, and one of the most complete carbonate successions of this age reported in the northern Tethyan margin. The host limestones (Benassal Formation) are partially replaced by dolostones providing a new case study of fault-controlled hydrothermal dolomitization. The syn-rift sediments filled a graben controlled by normal basement faults. The Benassal Fm was deposited in a carbonate ramp with scarce siliciclastic input. The lithofacies are mainly characterized by the presence of orbitolinid foraminifera, corals and rudist bivalves fauna. The succession is stacked in three transgressive-regressive sequences $(T-R)$ bounded by surfaces with sequence stratigraphic significance. The third sequence, which is reported for the first time in the basin, is formed by fully marine lithofacies of Albian age and represents the marine equivalent to the continental deposits of the Escucha Fm in the rest of the basin.

The dolomitization of the host rock is spatially associated with the basement faults, and thus is faultcontrolled. The dolostone forms seismic-scale stratabound tabular geobodies that extend several kilometres away from the fault zones, mostly in the hanging wall blocks, and host Mississippi Valley Type (MVT) deposits. The dolostones preferentially replaced middle to inner ramp grain-dominated facies from the third $\mathrm{T}-\mathrm{R}$ sequences consisting of bioclastic packestones and peloidal grainstones. Field and petrology data indicate that the replacement took place after early calcite cementation and compaction, most likely during the Late Cretaceous post-rift stage of the basin. The dolostone registers the typical hydrothermal paragenesis constituted by the host limestone replacement, dolomite cementation and sulfide MVT mineralization. The Aptian succession studied provides a stratigraphic framework that can be used for oil exploration in age-equivalent rocks, especially in the València Trough, offshore Spain. Moreover, this new case study constitutes a world class outcrop analogue for similar partially stratabound, dolomitized limestone reservoirs worldwide.
\end{abstract}

\footnotetext{
* Corresponding author. Departament de Petrologia, Geoquímica i Prospecció Geològica, Universitat de Barcelona, 08028 Barcelona, Spain.

E-mail address: juandiegomartin@ub.edu (J.D. Martín-Martín).
}

\section{Introduction}

During the Aptian, extensive carbonate platforms dominated by orbitolinids, corals and rudists developed throughout the Tethyan realm (e.g., Skelton and Gili, 2012). Some of these platform successions, such as the Shu'aiba Fm in the Arabian Plate, constitute 
nowadays prolific oil reservoirs (e.g., Droste, 2010; Hillgärtner et al., 2003; van Buchem et al., 2010). In eastern Iberia, the Aptian record displays a lithofacies evolution and accommodation changes similar to those identified in coeval rocks of Arabia and of other basins of the Tethys (Bover-Arnal et al., 2009b, 2010, 2011a; Embry et al. 2010). Thus, these Iberian carbonates provide consistent analogues for the study of Aptian subsurface carbonate reservoirs elsewhere.

Outcrop analogues allow a continuous observation of spatial patterns of reservoir and non-reservoir rocks, including key parameters for the oil industry such as porosity and permeability (e.g., Sharp et al., 2010; Koehrer et al., 2010). The distribution of these rock heterogeneities is basically controlled by the depositional lithofacies, the diagenetic history and the structural framework. In major carbonate assets of the Middle East (e.g., North Field; Jones et al., 2011) there is a spatial relationship between faults and dolostones. Predicting reservoir quality between wells or ahead of the bit is a challenge without understanding the controls on the dolomitization processes. Fault-controlled dolomitized reservoirs host some of the major oil reserves in the world, mainly in the Middle East and North America (Davies and Smith, 2006).

The Early Cretaceous, syn-rift shallow-marine carbonates of the Benassal Fm in the Benicàssim area (Maestrat Basin, E Spain) form an exceptionally thick succession that appears partially dolomitized in close proximity to regional, seismic-scale faults (Fig. 1). The replacement of the Benassal Fm limestones resulted in seismic scale dolostone geobodies with a preferential stratabound distribution (Gomez-Rivas et al., 2010, 2012; Martín-Martín et al., 2010, 2012). The investigation of these well-exposed platform carbonates is of significance as they allow documentation of two exceptional features. First, they represent the thickest Aptian to Albian syn-rift succession of the Maestrat Basin and one of the most complete carbonate sedimentary record of this age reported for the Tethys. Second, the replacive dolostones constitute an illustrative case study of fault-controlled hydrothermal dolomitization that provides data about structural, depositional and diagenetic controls on the replacement processes.

The aims of this paper are: (1) to document and describe the facies architecture of the Benassal Fm in the Benicàssim area; (2) to establish a sequence stratigraphic framework for this succession; (3) to evaluate the accommodation changes that controlled its deposition; and (4) to describe the distribution and geometry of the partial dolomitization affecting the host rock.

\section{Geologic setting}

The Maestrat Basin is located in the eastern part of the Iberian Chain (Fig. 1), which is an intraplate range that resulted from the Paleogene (Late Eocene-Early Oligocene) inversion of the NW-SEtrending Iberian Rift Basin. The Iberian Rift developed between the Late Permian and the Late Cretaceous in two major stages of rifting, followed by two thermal subsidence post-rift stages (Salas and Casas, 1993; Salas et al., 2001). The Maestrat Basin became compartmentalized during the Late Jurassic-Early Cretaceous rifting cycle into seven sub-basins limited by normal faults (Salas et al., 2001) (Figs. 1 and 2). Following the Alpine inversion of the basin, a new extensional event took place during the Neogene (Oligocene-Miocene) (Roca and Guimerà, 1992; Salas et al., 2001). This extension structured the València Trough and the present-day coastline of eastern Spain.

The study area (Benicàssim area) is located in the southern Maestrat Basin (Penyagolosa sub-basin) and constitutes the eastern margin of the Desert de les Palmes Ranges (Fig. 1). The structure of the Desert de les Palmes is characterized by a system of NE-SW to NNE-SSW trending and NW dipping basement faults displaying Triassic to Lower Cretaceous rocks in their footwall as well as narrow strips of Palaeozoic to the SW of the study area (Roca et al., 1994; Salas et al., 1995; Martín-Martín et al., 2005). At a smaller spatial

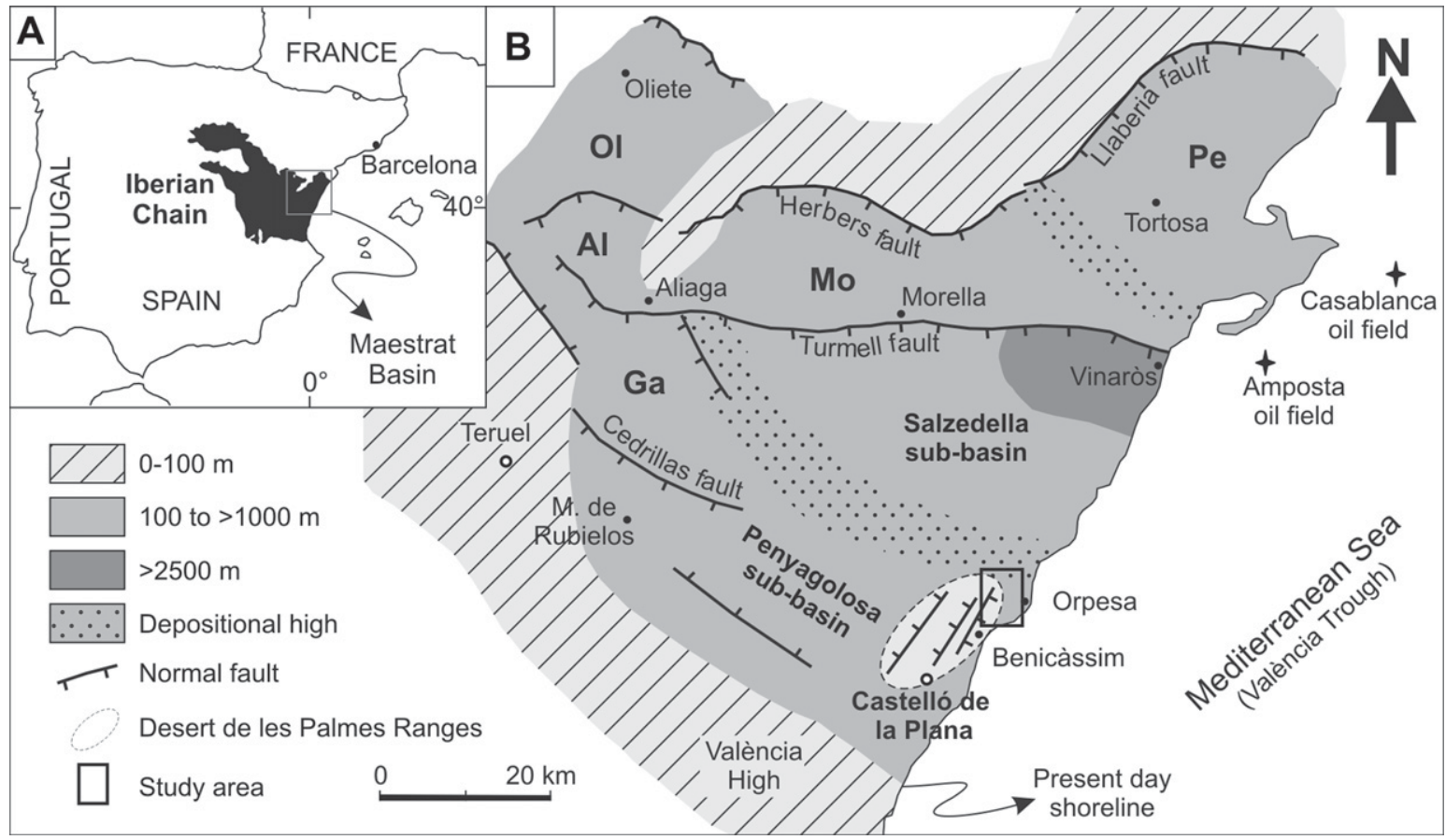

Fig. 1. (A) Simplified map of the Iberian Peninsula showing the location of the Maestrat Basin within the Iberian Chain; (B) Palaeogeographic map of the Maestrat Basin showing the thickness of the Late Jurassic-Early Cretaceous succession along the basin. Besides Salzedella and Penyagolosa, other minor sub-basins are labelled as Mo (Morella), Pe (El Perelló), Ol (Oliete), Ga (Galve) and Al (Aliaga) (modified from Salas et al., 2001). 


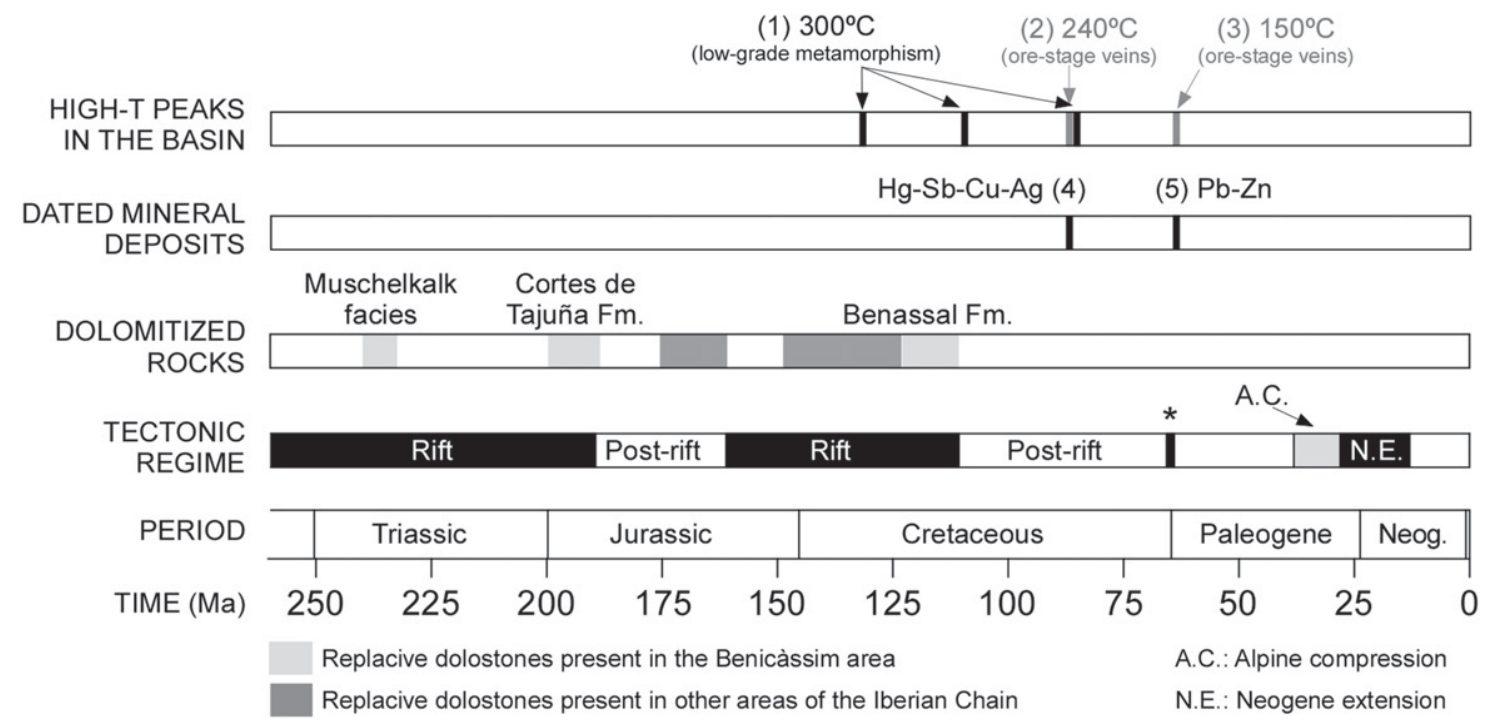

Fig. 2. Summary of most important geologic events in the Maestrat Basin. Timing of tectonic regimes after Salas et al. (2001) except Early Tertiary rift (*) after Grandia et al. (2000). Temperature peaks and dates have been taken from: (1) Martín-Martín (2004), (2) Tritlla and Cardellach (1997), (3) Grandia et al. (2000), (4) Tritlla and Solé (1999) and (5) Grandia et al. (2003).

scale, the area investigated is mainly structured by the Benicàssim fault, with NNE-SSW trend and SE dip, which intersects the E-Wstriking and S-dipping Campello and Juvellús faults (Gomez-Rivas et al., 2012) (Fig. 3). The activity of the Benicàssim and Campello faults was especially intense during the Late Jurassic-Early Cretaceous rifting episode, resulting in the deposition of a thick Early Cretaceous sedimentary succession in the hanging wall of both structures (Roca et al., 1994; Salas et al., 1995) (Figs. 1 and 3). Both sets of faults show stratigraphic offsets over $1 \mathrm{~km}$ (seismic-scale) probably involving the Palaeozoic basement (Gomez-Rivas et al., 2012). The same cross-cutting relationship between both fault systems is commonly observed in other areas of the southern and eastern Maestrat Basin (e.g., Antolín-Tomás et al., 2007). In addition to the major faults, subseismic-scale fractures with very low offsets and sub-parallel to them are present in the Benicàssim area. Most of these Early Cretaceous faults and fractures were reactivated during the Alpine deformation (Gomez-Rivas et al., 2012), as was previously reported from other areas of the Maestrat Basin (e.g., Liesa and Simón, 2009). The final regional tilt of the entire succession towards the $\mathrm{N}$ is related to the Neogene extension period (e.g., AntolínTomás et al., 2007 and references therein) (Figs. 2 and 3).

The Early Cretaceous succession of the Benicàssim area is formed by the Barremian Artoles Fm, and the Aptian Cervera, Xert, Forcall, Villarroya de los Pinares and Benassal formations (Canérot et al., 1982; Salas et al., 1995, 2001) (Fig. 3). This paper focused in the Benassal Fm, which consists of shallow-marine carbonates characterized by the occurrence of rudist-, coral- and orbitolinidrich facies (Comas, 2006; Riding and Tomás, 2006; Salas et al., 1995; Skelton and Gili, 2012; Tomás et al., 2007, 2008). The Benassal Fm has been dated as Late Aptian based on orbitolinids (Canérot et al., 1982; Neumann, 1987; Salas et al., 1995, 2001; Tomás et al., 2007, 2008) and ammonites (Salas et al., 1995, 2001). Recently, the collection of new ammonite specimens in several successions along the Maestrat Basin allowed revised dating of the Benassal Fm, with an age ranging from latest Early Aptian to Late Aptian (Moreno-Bedmar et al., 2009b, 2012; Bover-Arnal et al., 2009b, 2010, 2011b, 2012).

The Benassal Fm carbonates of the Benicàssim area are partially replaced by ferroan dolostones locally hosting Mississippi Valley Type (MVT) deposits (Salas et al., 1986; Salas et al., 1995;
Climent-Domènech et al., 2007; Gomez-Rivas et al., 2010; MartínMartín et al., 2010). The model age of the MVT deposits, based on $\mathrm{U}-\mathrm{Pb}$ data, hosted by the Early Cretaceous carbonates elsewhere in the Maestrat Basin is $62.6 \pm 0.7 \mathrm{Ma}$ (Early Paleocene) (Grandia et al., 2000) (Fig. 2).

\section{Methods}

The spatial distribution of the dolomitized geobodies was mapped in detail within an area of $\sim 43 \mathrm{~km}^{2}$ (Fig. 3). The geologic map is partially based on a previous map of the same area by Climent-Domènech et al. (2007), as well as the Spanish Regional Map (MAGNA) by Obis et al. (1973).

The Benassal Fm (dolostone host limestone) was characterized along the Orpesa Range by logging three stratigraphic successions named Racó de Rita (3), Racó de Llanes (4) and Racó del Moro (5) (Fig. 3). The studied sections were correlated with one another and with equivalent successions from the Orpesa Range reported by Comas (2006) and Tomás et al. (2007). Correlation was based on field data, photo panels, bedding traces, and characteristic facies.

A total of 202 samples were collected along the Benassal Fm from the three logged stratigraphic successions. The Racó del Moro site was selected for detailed investigation and sampling of the dolomitized geobodies on the basis of the good exposure and lateral continuity. Limestone and dolostone petrography is based on the analysis of thin sections by standard transmission microscopy (Zeiss Axiophot equipment). Selected thin sections were previously half stained with alizarin red-S and potassium ferricyanide in order to identify ferroan and non-ferroan calcite and dolomite. Lithofacies types (LFT) were defined based on field and petrography data including lithology, texture, bioclastic and non-bioclastic components and sedimentary structures. The lithofacies types are based on previous facies studies from the same area by Comas (2006), Tomás (2007) and Tomás et al. (2007). The inferred depositional environments (basin, inner-, middle- and outer-ramp) are termed following Burchette and Wright (1992).

A transgressive-regressive (T-R) sequence stratigraphic analysis (see Catuneanu et al., 2009) was performed along the Benassal Fm succession. Due to the difficulty of precisely identifying the maximum flooding surface (MFS) within the sequences, 


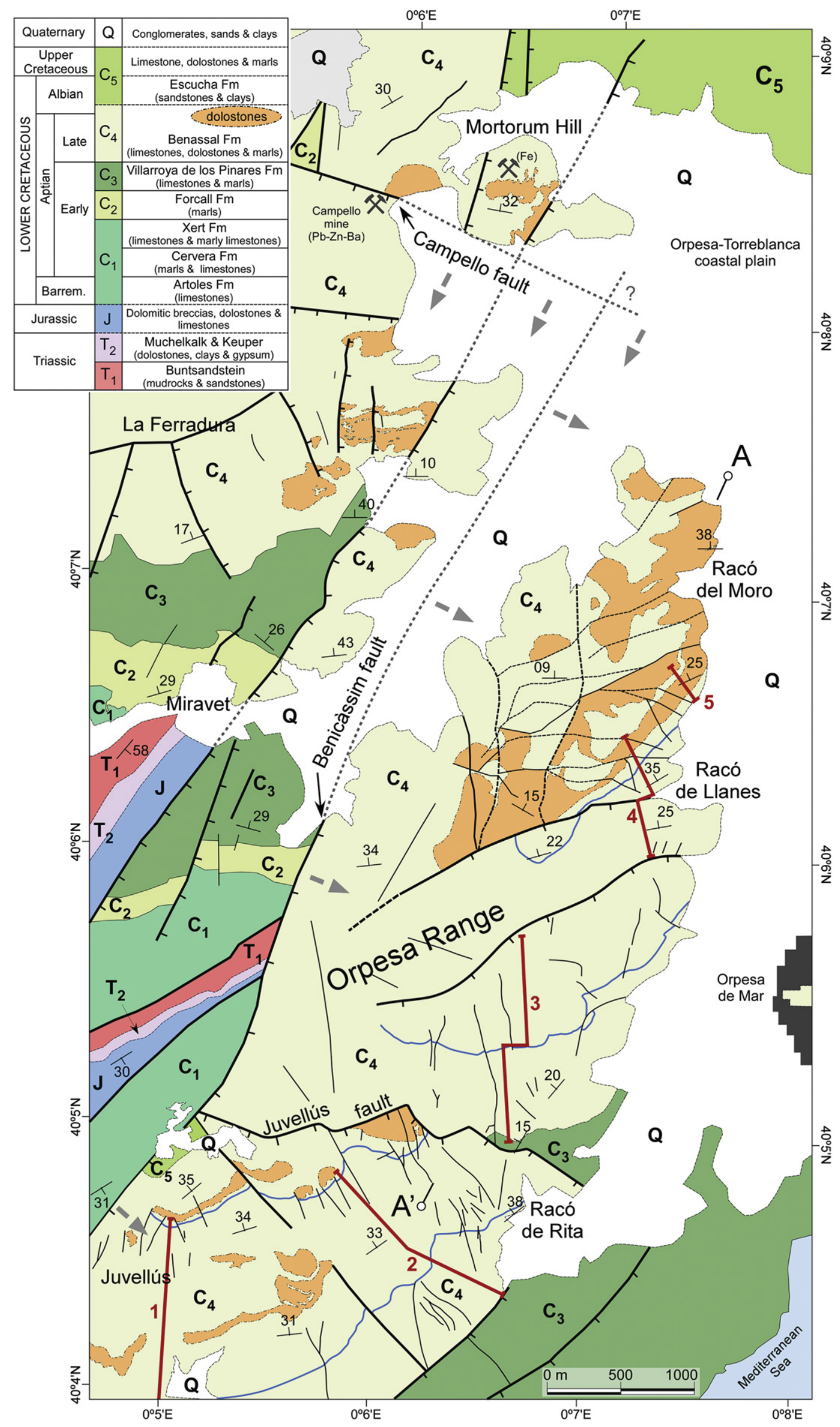


a maximum flooding zone (MFZ) (sensu Strasser et al., 1999) was characterized instead. The ages of the Benassal Fm and the reported $\mathrm{T}-\mathrm{R}$ sequences were partially calibrated by means of ammonoids and orbitolinids.

The evaluation of the burial history was carried out by quantitative subsidence analysis using standard back-stripping methods (Sclater and Christie, 1980; Watts, 1981; Bond and Kominz, 1984). The total subsidence (decompacted) was calculated using the Decompact Excel sheet macro created by D. Waltham (Royal Holloway, University of London), which is based on the method of Allen and Allen (1990). The subsidence analysis of the local Aptian stratigraphic succession was based on our own field data and the regional geology reported in the literature (Obis et al., 1973; Salas and Casas, 1993; Salas and Guimerà, 1996; Salas et al., 2001; Roca et al., 1994; Martín-Martín, 2004). Variables used to calculate the subsidence of each sedimentary unit include lithology, palaeobathymetry and absolute age (after Ogg and Ogg, 2006). Decompaction was calculated using density values and porosity/depth relationships ( $c$ factors) for each lithology type (Sclater and Christie, 1980; Schmoker and Halley, 1982). No eustatic corrections were performed. The Aptian $\mathrm{T}-\mathrm{R}$ sequences, as well as their ages, are defined following the stratigraphic work by Bover-Arnal et al. (2010).

\section{Results}

\subsection{Sequence stratigraphy and lithofacies evolution}

Twelve lithofacies types (LFT) are recognized throughout the Benassal Fm succession of the study area which are summarized in Table 1 and illustrated in Figs. 4-6. Additionally, based on the identification of key stratigraphic surfaces and stacking patterns, three transgressive-regressive ( $\mathrm{T}-\mathrm{R}$ ) sequences (III, IV and $\mathrm{V}$ ) are recognized (Bover-Arnal et al., 2009a) (Figs. 7 and 8). The boundary between the Benassal Fm and the underlying Villarroya de los Pinares Fm is marked by an abrupt lithological change from wellbedded platform bioclastic grainstones (below) to grey marls (above). This surface, which exhibits iron stains, is interpreted as a maximum regressive surface (MRS) (Fig. 8). The equivalent transition between both formations has been recognized elsewhere in the Maestrat Basin as a sequence boundary with palaeokarst features concealed by a hardground (Bover-Arnal et al., 2010, 2011b).

The $\mathrm{T}-\mathrm{R}$ Sequence III is around $410-\mathrm{m}$ thick, with a $90-\mathrm{m}$ thick transgressive system tract (TST) and a 320-m thick regressive system tract (RST) (Figs. 7 and 8). The TST is characterized by the predominance of green marls (LTF1) with frequent metre-thick intercalations of cross-bedded peloidal and orbitolinid packstones to grainstones with erosive bases and ferruginous grains (LTF2) (Fig. 4A-C). This transgressive marl unit crops out extensively in the Racó de Rita section, but it is reduced by fault in the Juvellús and La Venta sections (Fig. 3). Ammonite species collected within the marls are Epicheloniceras sp., Epicheloniceras cf. debile Casey, Colombiceras sp. and Caseyella sp. (Fig. 9). The maximum flooding zone (MFZ) of Sequence III is placed towards the top of the thickest marl unit.

Above the MFZ, the lower part of the RST is characterized by the presence of two well-bedded ochre-coloured metre to tens of metre-thick coarsening and thickening upwards cycles of peloidal and orbitolinid packstones to grainstones (LTF2) (Fig. 4B, C). The basal grainstones exhibit large-scale cross-stratification indicating progradation from west to east. The regressive sequence follows with a second and thinner marl unit (LTF1) showing metre-thick cross-bedded grainstones (LTF2). The ammonite specimens collected within this second marly unit are Parahoplites $\mathrm{cf}$. vectensis Casey, which is characteristic of the Parahoplites melchioris biozone. The upper part of the RST is constituted by peloidal grainstones (LTF3), orbitolinid wackestone to rudstone (LTF4) and coral-rich facies (LTF5 and LTF6) (Figs. 4D-F, 5A). In La Venta and Juvellús sections, these facies exhibit a basal coral sheetstone (LTF5) that is overlain by a thick platy- to domal-rich coral limestone (LTF6). In the Racó de Rita section, the corals, which are present together with rudists and Chondrodonta bivalves, are dominantly reworked. These skeletal components appear intensively encrusted by Lithocodium aggregatum Elliott and cellular structures of unknown taxonomic origin sensu Schlagintweit et al. (2010). Moreover, the corals show frequent borings by lithophagid bivalves. Above the coral limestones, the RST ends with a thick rudist floatstone bed-set (LTF7) containing abundant requieniids (Toucasia sp.), polyconitids (Polyconites sp.), clusters of radiolitids (Archaeoradiolites sp.) and monopleurids (Mathesia), and nerineid gastropods (Fig. 5B, C). Chondrodonta bivalves are also present, locally being the main component of the floatstone (Fig. 5D). The upper boundary of the sequence is distinguished by a maximum regressive surface displaying intense bioturbation, which is identified in the Racó de Rita, Juvellús and La Venta sections (Fig. 8).

The T-R Sequence IV is around 710-m-thick, being the thickest sequence reported here. The transgressive deposits are characterized by the occurrence of tidally-influenced grainstones with quartz and mica (LTF8), which record a local influx of siliciclastics (Fig. 5E). The rest of the TST is mainly constituted by micritedominated deposits, consisting of orbitolinid-rich facies (LTF4), and sponge spicule wackestones (LTF9) (Figs. 4E, 5F). The MFZ of the Sequence IV is placed around the top of the latter lithofacies type (Figs. 7 and 8 ).

The lower part of the RST is characterized by three sets of coralbearing limestones, which form tabular beds that are laterally continuous along the Orpesa Range (Fig. 8). Commonly, the bed-set exhibits a basal coral sheetstone (LTF5) overlain by a thick platy- to domal-rich coral limestone (LTF6) (Figs. 4F, 5A). These regressive strata are stacked in a prograding pattern and display downlap geometries. Fossilized syn-sedimentary normal faults affect these levels (Fig. 7C). In the Racó de Llanes section, the top of the RST is marked by a sharp surface that separates a requieniid-dominated floatstone (LTF7), with occasional clusters of radiolitids and abundant iron stained grains, from the overlying grainstones with hummocky cross-stratification (LTF10).

The upper part of the RST in Sequence IV is characterized by the presence of ochre-coloured, cross-bedded packstones to grainstones with hummocky cross-stratification and graded beds, which contain some aligned skeletal lags (LTF10) (Fig. 6A, B). Three bedsets of these facies, organized in coarsening and thickening cycles, are recognized in the Racó de Llanes section. Commonly, the cycles exhibit an orbitolinid-rich marly wackestone to rudstone base. Above, the RST ends with a package of rudist-dominated floatstones that can be followed along the Orpesa Range, and thus is used as a correlation datum (Fig. 8). These floatstones are characterized by the presence of abundant requieniids (Toucasia sp.) and scarce polyconitids (Polyconites sp.). Clusters of radiolitids and monopleurids (Monopleura sp.) are locally abundant. In the

Fig. 3. Geologic map of the Benicàssim area (see Fig. 1 for location) showing the distribution of the dolostones and their spatial association with the Benicàssim and the Campello faults (modified from Martín-Martín et al., 2012). Red lines 1-5 and bedding traces in blue colour correspond to sections and sequence boundaries, respectively (see Fig. 8). A- $\mathrm{A}^{\prime}$ denotes the trace of the field view in Fig. 7A. (For interpretation of the references to colour in this figure legend, the reader is referred to the web version of this article.) 
Table 1

Summary of most important characteristics and interpretation of lithofacies types (LFT).

\begin{tabular}{|c|c|c|c|c|c|c|}
\hline $\begin{array}{l}\text { Lithofacies type } \\
\text { (LFT) }\end{array}$ & $\begin{array}{l}\text { Characteristic } \\
\text { components }\end{array}$ & Secondary components & Sedimentary features & Sorting & $\begin{array}{l}\text { Bedding } \\
\text { thickness }\end{array}$ & $\begin{array}{l}\text { Environmental } \\
\text { interpretation }\end{array}$ \\
\hline 1. Green marl & $\begin{array}{l}\text { Echinoids, } \\
\text { brachiopods } \\
\text { (Rhynchonellida and } \\
\text { Terebratulida) and } \\
\text { bivalves }\end{array}$ & $\begin{array}{l}\text { Ammonites, gastropods, } \\
\text { undifferentiated bioclasts }\end{array}$ & $\begin{array}{l}\text { Nodular bedding, } \\
\text { laminar siltstones }\end{array}$ & Poor & $\begin{array}{l}\text { Metric to } \\
\text { tens of } \\
\text { metres }\end{array}$ & $\begin{array}{l}\text { Low-energy, } \\
\text { outer ramp }\end{array}$ \\
\hline $\begin{array}{l}\text { 2. Cross-bedded } \\
\text { peloidal and } \\
\text { orbitolinid } \\
\text { packstone to } \\
\text { grainstone }\end{array}$ & $\begin{array}{l}\text { Peloids, echinoids, } \\
\text { orbitolinids, } \\
\text { miliolids }\end{array}$ & $\begin{array}{l}\text { Bivalves, coated grains, quartz, } \\
\text { glauconite, dasyclad algae, other } \\
\text { foraminifera, ooids, gastropods, other } \\
\text { molluscs, aggregate grains, intraclasts }\end{array}$ & $\begin{array}{l}\text { Tabular bedding, high- } \\
\text { to low-angle cross- } \\
\text { stratification, sharp } \\
\text { bases (occasionally) }\end{array}$ & $\begin{array}{l}\text { Poor to } \\
\text { moderate }\end{array}$ & $\begin{array}{l}\text { Decimetric } \\
\text { to metric }\end{array}$ & $\begin{array}{l}\text { Low- to } \\
\text { moderate- } \\
\text { energy, inner } \\
\text { to outer ramp }\end{array}$ \\
\hline $\begin{array}{l}\text { 3. Peloidal } \\
\text { grainstone }\end{array}$ & Peloids, miliolids & $\begin{array}{l}\text { Coated grains, echinoids, orbitolinids, } \\
\text { sessile foraminifera, quartz }\end{array}$ & $\begin{array}{l}\text { Massive bedding, } \\
\text { bioturbation, sharp } \\
\text { bases (occasionally) }\end{array}$ & $\begin{array}{l}\text { Good to } \\
\text { very } \\
\text { good }\end{array}$ & $\begin{array}{l}\text { Decimetric } \\
\text { to metric }\end{array}$ & $\begin{array}{l}\text { Moderate- } \\
\text { energy, inner } \\
\text { to middle ramp }\end{array}$ \\
\hline $\begin{array}{l}\text { 4. Orbitolinid } \\
\text { wackestone to } \\
\text { rudstone and } \\
\text { marl }\end{array}$ & Orbitolinids & $\begin{array}{l}\text { Peloids, miliolids, echinoids, other } \\
\text { foraminifera, bivalves, gastropods, other } \\
\text { molluscs }\end{array}$ & $\begin{array}{l}\text { Massive to wavy } \\
\text { bedding }\end{array}$ & $\begin{array}{l}\text { Poor to } \\
\text { good }\end{array}$ & $\begin{array}{l}\text { Centimetric } \\
\text { to metric }\end{array}$ & $\begin{array}{l}\text { Low- to high- } \\
\text { energy, inner } \\
\text { to outer ramp }\end{array}$ \\
\hline 5. Coral sheetstone & Sheet-like corals & $\begin{array}{l}\text { Encrusting red algae, foraminifers, } \\
\text { Lithocodium aggregatum, sponge } \\
\text { spicules, peloids }\end{array}$ & Slightly marly bedding & Poor & $\begin{array}{l}\text { Decimetric } \\
\text { to metric }\end{array}$ & $\begin{array}{l}\text { Low-energy, } \\
\text { inner to middle } \\
\text { ramp }\end{array}$ \\
\hline 6. Coral limestone & $\begin{array}{l}\text { Platy, tabular and } \\
\text { domal corals }\end{array}$ & $\begin{array}{l}\text { Encrusting red algae, Lithocodium } \\
\text { aggregatum, orbitolinids, other } \\
\text { foraminifera, echinoids, peloids }\end{array}$ & $\begin{array}{l}\text { Tabular massive to } \\
\text { nodular bedding, } \\
\text { lithophagid borings }\end{array}$ & Poor & Metric & $\begin{array}{l}\text { Low-energy, } \\
\text { inner to middle } \\
\text { ramp }\end{array}$ \\
\hline $\begin{array}{l}\text { 7. Rudist } \\
\text { floatstone to } \\
\text { rudstone }\end{array}$ & $\begin{array}{l}\text { Requieniid and } \\
\text { elevator rudists }\end{array}$ & $\begin{array}{l}\text { Chondrodonta bivalves, nerineid } \\
\text { gastropods, other molluscs, orbitolinids, } \\
\text { miliolids, other foraminifera, } \\
\text { Lithocodium aggregatum, peloids }\end{array}$ & $\begin{array}{l}\text { Tabular massive to } \\
\text { slightly nodular } \\
\text { bedding }\end{array}$ & Poor & Metric & $\begin{array}{l}\text { Low- to } \\
\text { moderate- } \\
\text { energy, inner } \\
\text { to middle ramp }\end{array}$ \\
\hline $\begin{array}{l}\text { 8. Grainstone with } \\
\text { siliciclastic } \\
\text { influence }\end{array}$ & $\begin{array}{l}\text { Echinoids, peloids, } \\
\text { intraclasts }\end{array}$ & $\begin{array}{l}\text { Quartz, mica, miliolids, orbitolinids, } \\
\text { other foraminifera, glauconite }\end{array}$ & $\begin{array}{l}\text { Cross-bedding, tidal } \\
\text { bundles, herring-bone } \\
\text { stratification }\end{array}$ & $\begin{array}{l}\text { Poor to } \\
\text { moderate }\end{array}$ & Metric & $\begin{array}{l}\text { Moderate- } \\
\text { energy, inner } \\
\text { to outer ramp }\end{array}$ \\
\hline $\begin{array}{l}\text { 9. Spicule } \\
\text { wackestone }\end{array}$ & $\begin{array}{l}\text { Sponge spicules, } \\
\text { undifferentiated } \\
\text { shell debris }\end{array}$ & $\begin{array}{l}\text { Bivalves, gastropods, orbitolinids, sessile } \\
\text { foraminifera, other foraminifera }\end{array}$ & $\begin{array}{l}\text { Massive to wavy } \\
\text { bedding, bioturbation }\end{array}$ & $\begin{array}{l}\text { Poor to } \\
\text { moderate }\end{array}$ & Metric & $\begin{array}{l}\text { Low-energy, } \\
\text { outer ramp }\end{array}$ \\
\hline $\begin{array}{l}\text { 10. Grainstone } \\
\text { with } \\
\text { hummocky } \\
\text { cross- } \\
\text { stratification }\end{array}$ & Peloids, orbitolinids & $\begin{array}{l}\text { Echinoids, miliolids, bivalves, ooids, } \\
\text { aggregate grains, other molluscs, other } \\
\text { foraminifera }\end{array}$ & $\begin{array}{l}\text { Cross-bedding, } \\
\text { hummocky cross- } \\
\text { stratification, bioclastic } \\
\text { lags, graded beds }\end{array}$ & $\begin{array}{l}\text { Poor to } \\
\text { moderate }\end{array}$ & $\begin{array}{l}\text { Centimetric } \\
\text { to decimetric }\end{array}$ & $\begin{array}{l}\text { Moderate- } \\
\text { energy, middle } \\
\text { ramp }\end{array}$ \\
\hline $\begin{array}{l}\text { 11. Bioclastic } \\
\text { wackestone to } \\
\text { packstone }\end{array}$ & $\begin{array}{l}\text { Bivalves, other } \\
\text { molluscs, sessile } \\
\text { foraminifera, } \\
\text { miliolids }\end{array}$ & $\begin{array}{l}\text { Peloids, echinoids, orbitolinids, sponge } \\
\text { spicules, Ostracoda, gastropods, coated } \\
\text { grains, undifferentiated bioclasts, } \\
\text { Lithocodium aggregatum }\end{array}$ & $\begin{array}{l}\text { Massive to wavy } \\
\text { bedding, bioturbation }\end{array}$ & Poor & $\begin{array}{l}\text { Decimetic } \\
\text { to metric }\end{array}$ & $\begin{array}{l}\text { Low- to } \\
\text { moderate- } \\
\text { energy, inner } \\
\text { to outer ramp }\end{array}$ \\
\hline $\begin{array}{l}\text { 12. Ooid } \\
\text { grainstone }\end{array}$ & Ooids & $\begin{array}{l}\text { Peloids, echinoids, other foraminifera, } \\
\text { glauconite, miliolids }\end{array}$ & Cross-bedding & $\begin{array}{l}\text { Good to } \\
\text { very } \\
\text { good }\end{array}$ & $\begin{array}{l}\text { Centimetric to } \\
\text { decimetric }\end{array}$ & $\begin{array}{l}\text { High-energy, } \\
\text { inner to middle } \\
\text { ramp }\end{array}$ \\
\hline
\end{tabular}

Racó de Llanes section most of the rudists shells are reworked. Due to the lack of subaerial exposure features, the top of this sequence is interpreted to correspond to a maximum regressive surface (MRS), which separates the regressive rudist-rich floatstones from transgressive nodular-bedded bioclastic limestones containing mud drapes (LTF11) (Figs. 7 and 8).

The $T-R$ Sequence $V$ crops out extensively in the northern margin of the Orpesa Range (Racó del Moro and Racó de Llanes sections) and reach a thickness of around $380 \mathrm{~m}$ (Figs. 7 and 8). The TST is characterized by the presence of several metre-thick coarsening and thickening upwards cycles grading from bioclasticdominated wackestones to poorly-sorted packstones (LTF11) (Fig. 6C). The cycles are often topped by floatstones with small bouquets of rudists (radiolitids and polyconitids) and Chondrodonta bivalves (LTF7) (Fig. 5D). These transgressive cycles extend laterally over hundreds of metres. Towards the upper part of these bed-sets the host limestone is replaced by medium to coarse crystalline dolostones that form a characteristic brown tabular interval within the Sequence V (Figs. 7 and 8). Non-dolomitized beds, exhibiting mudstone to wackestone textures and containing sponge spicules and orbitolinids (LTF9), occur within the dolomitized interval
(Fig. 5F). The MFZ of the third sequence is placed at the sponge spicule-rich beds. Above, the RST of Sequence V follows with oolitic grainstones (LTF12), which are extensively cemented by calcite (Fig. 6D), and peloidal packstones to grainstones (LTF3) (Fig. 4D). A second dolomitized interval of several metres thick characterizes the top of the succession. The uppermost part of the third sequence, and thus the top of the Benassal Fm, is formed by limestones containing siliciclastic particles (quartz and mica) (LTF8). At a basin-scale, the top boundary of the Benassal Fm corresponds to an unconformity overlain by the sandstones and clays of the Escucha Fm (Salas et al., 2001).

\subsection{Total subsidence analysis}

The total subsidence curve calculated for the Aptian succession shows the accommodation changes associated with the syn-rift activity of the Benicàssim and the Juvellús faults (Fig. 10). The curve was calculated taking into account the thickness of the Benassal Fm measured along the Orpesa Range (hanging wall position) and the thickness of the Cervera, Xert, Forcall and Villarroya de los Pinares formations reported in the literature (Obis et al., 

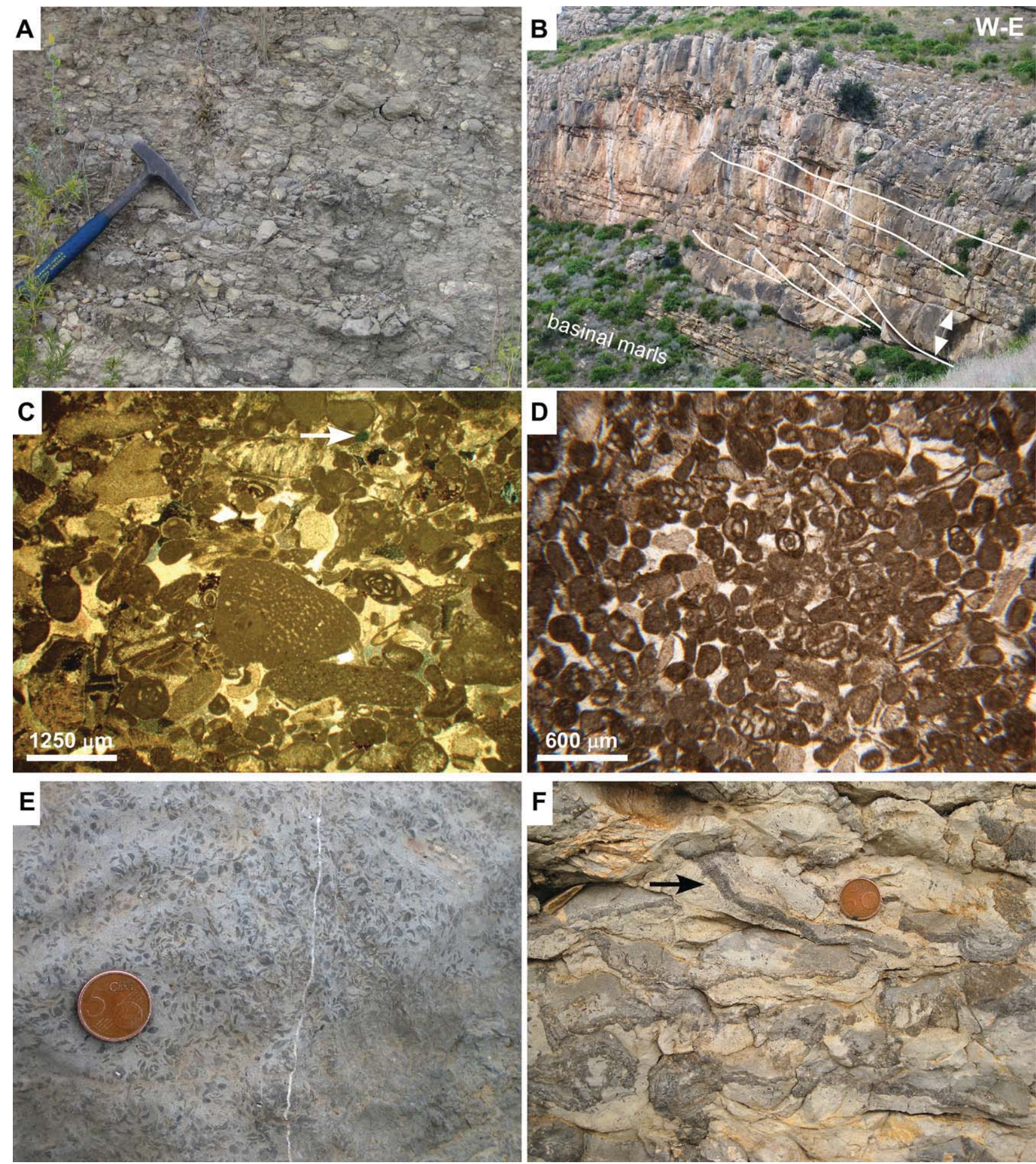

Fig. 4. (A) Field view showing green coloured marls with calcitic nodules (LFT1). (B) Field view of a cross-bedded peloidal and orbitolinid grainstone bed-set showing large-scale cross-bedding (white line) (LFT2). The bed in the bottom right corner is around 2 m-thick (arrowed). (C) Photomicrograph of LFT2 showing peloids, orbitolinids, miliolids and glauconite (arrowed). (D) Photomicrograph of a peloidal grainstone (LFT3) with abundant miliolids showing a well-sorted fabric. (E) Close view of an orbitolinid-dominated bed (LFT4). (F) Close view of a coral sheetstone (LFT5) showing platy corals encrusted by microbes (arrowed).

1973; Salas and Casas, 1993; Salas and Guimerà, 1996; Salas et al., 2001; Roca et al., 1994; Martín-Martín, 2004).

The curve allows visualizing the five stages of evolution of the Aptian platforms (Sequences I-V). The last three stages correspond to the Benassal Fm (Fig. 10). An initial stage of rapid subsidence occurred during the very Early Aptian (Sequence I) which, following Gradstein et al. (2004), took place between 125 and $124 \mathrm{Ma}$. Subsequently, the rate of subsidence slightly decreased during the Early Aptian (Sequence II) and kept mostly constant during most of the Late Aptian (Sequences III and IV), representing a time slice between 124 and $115.5 \mathrm{Ma}$. This period of constant subsidence rate is only disrupted by a discrete stage 

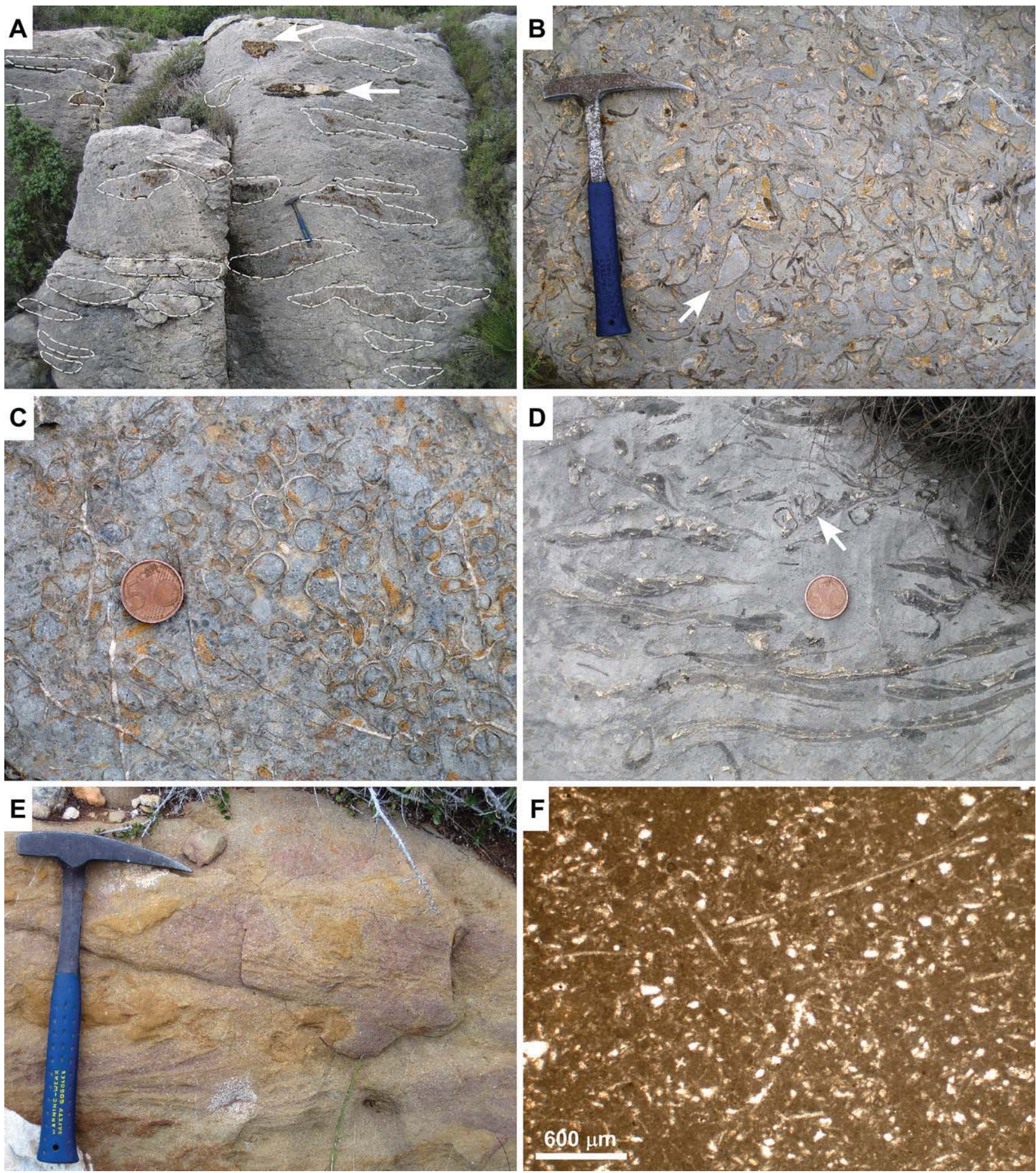

Fig. 5. (A) Field view of a matrix supported coral limestone (LFT6) showing tabular corals partially (dashed lines) to totally (arrowed) silicified. The corals float in a wackestone to packstone fabric. (B) Rudist-dominated floatstone (LFT7) showing abundant requieniids and polyconitids (arrowed). (C) Bouquet of rudist bivalves showing densely packed and small sized Mathesia specimens (LFT7). (D) Floatstone showing the common association of the Chondrodonta bivalves with rudist (LFT7). (E) Close view of a tidally-influenced grainstone showing bidirectional cross-bedding (LFT8). (F) Photomicrograph showing a sponge spicule wackestone (LFT9).

of rapid subsidence recorded during the onset of the Late Aptian (regressive deposits of Sequences III) ranging between 120.5 and $118 \mathrm{Ma}$. Finally, the rate of total subsidence considerably increased during the latest Late Aptian (regressive deposits of the Sequence IV) and kept constant until the Early Albian (Sequence V).

\subsection{Dolostone geobodies}

\subsubsection{Stratigraphic location and geometry}

The replacive dolostones form seismic-scale stratabound to substratabound tabular bodies within Sequence $\mathrm{V}$ and, in a lesser extent, within Sequence IV of the studied succession (Figs. 7, 8 and 

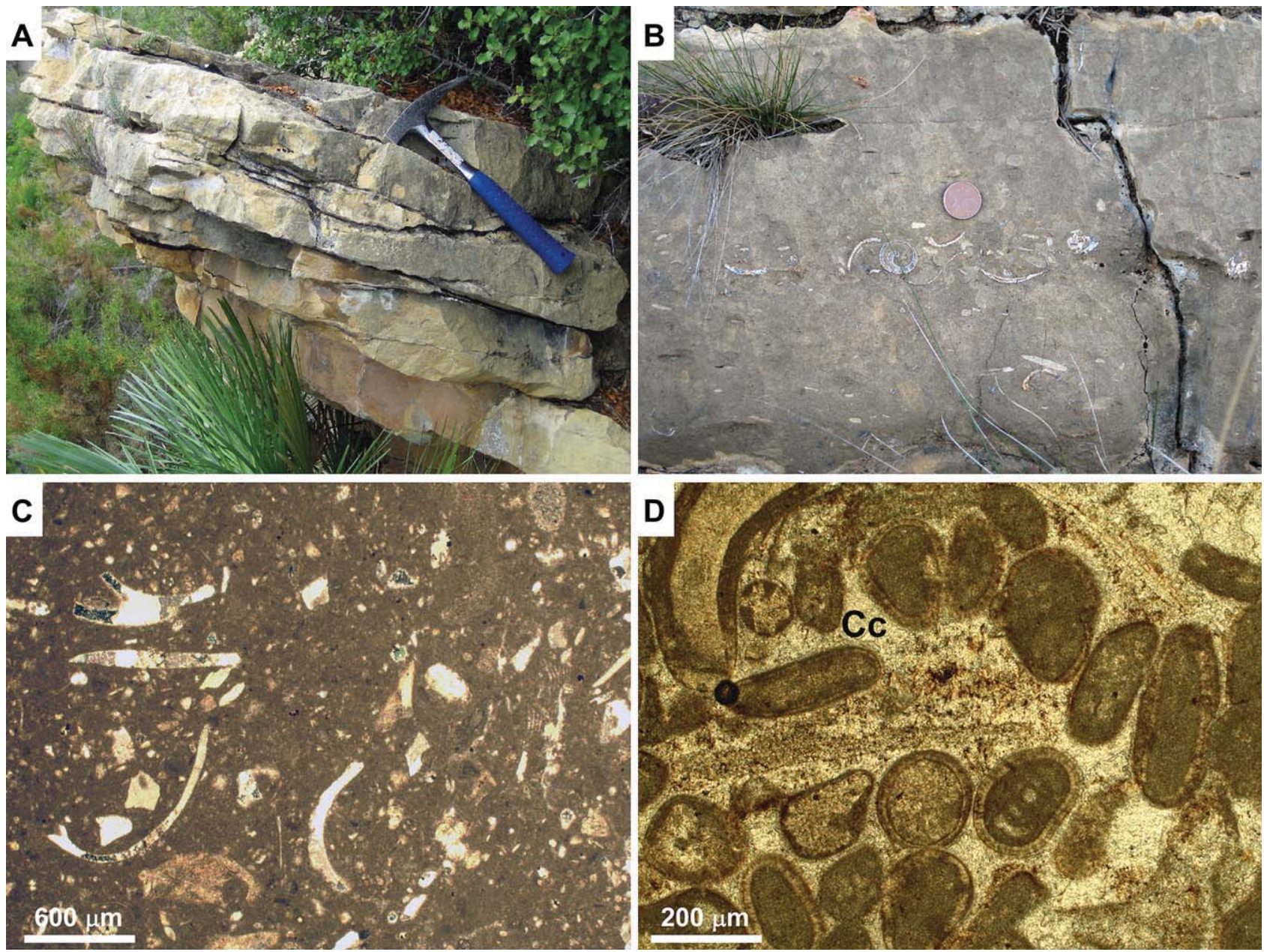

Fig. 6. (A) Field view of grainstone with HCS (LFT10) showing the characteristic ochre colour and cross-bedding. (B) Detail of a graded packstone (LFT10) showing the alignment of coarse sized bioclasts. (C) Photomicrograph of a bioclastic wackestone (LFT11) showing abundant bivalve debris and other unidentified skeletal fragments. (D) Photomicrograph of an ooid grainstone (LFT12) showing extensive cementation by calcite (Cc).

$11 \mathrm{~A}-\mathrm{E})$. The most extensive dolostone-bearing outcrops occur in the northern margin of the Orpesa Range, in the common hanging wall of the E-W trending Campello Fault and the NE-SW trending Benicàssim Fault (Fig. 3). The dolostone bodies extend between 1 and $7 \mathrm{~km}$ away from the Campello Fault, and between 0.2 and $2 \mathrm{~km}$ away from the Benicàssim Fault (distances measured perpendicular to the trend of the normal faults). The largest dolostone body, which extends over an area of several thousand square metres, exceeds a thickness of $100 \mathrm{~m}$ and crops out laterally along a distance of $6 \mathrm{~km}$. In addition, several smaller dolostone bodies are disseminated in the footwall of these faults and/or close to their intersection.

The contact between the host limestone and the dolostone bodies (dolomitization front) is recognized in the outcrops by the colour contrast (grey vs brown) between both lithologies (Fig. 11F). The dolomitization front is typically sharp, wavy, and cross-cuts the bedding in a range of decimetres to several metres. Less frequently, the dolomitization front follows the bedding perfectly (Fig 11D). Limestone beds are very tight and show frequent patches of pink coloured dolomite cement, especially in those locations next to the dolostone bodies and fractures. The original depositional fabric (stratification and/or lamination) is partially to completely preserved, whereas the dolomitized skeletal components are frequently emphasized in the weathered rock surface (Fig. 11G, H).
At the Racó del Moro site (Fig. 3), a nearly complete section of Sequence $\mathrm{V}$ crops out and two main stratabound dolostone bodies can be recognized (Fig. 11A and B). The lower one, which ranges between 75 and $125 \mathrm{~m}$ in thickness, partially replaces the transgressive and regressive bioclastic wackestone to packstone facies (LFT11), and peloidal grainstones (LFT3). Several nonreplaced limestone beds, which correspond to very tight micritedominated textures (LFT9), are intercalated within the dolostone body. Above the dolomitization front, the host limestone is formed by oolitic grainstones which are extensively cemented by calcite (LFT12). The upper dolostone body, which is around 25-m-thick, lies towards the top of Sequence $\mathrm{V}$ and replaces peloidal grainstone facies (LFT3). The uppermost part of the Benassal Fm consists of peloidal grainstones (LTF3) cemented by calcite and dolomite. Nonreplaced grain-dominated facies (LTF3 and LFT4) are present between the lower and the upper dolostone bodies.

In addition to dolostones, dolomite occurs also in limestones throughout the complete Benassal Fm succession. Dolomite cement partially fills, together with calcite, the intergranular pore-space in most grainy facies. It occurs abundantly in peloidal and orbitoliniddominated packstones to grainstones (LTF2), peloidal grainstones (LFT3) and grainstones with HCS (LFT10). Moreover, dolomite replaces originally aragonite or high-magnesium calcite skeletal components. In this sense, the original aragonitic inner shell of rudist bivalves appears commonly replaced by dolomite (Fig. 5B, C). 


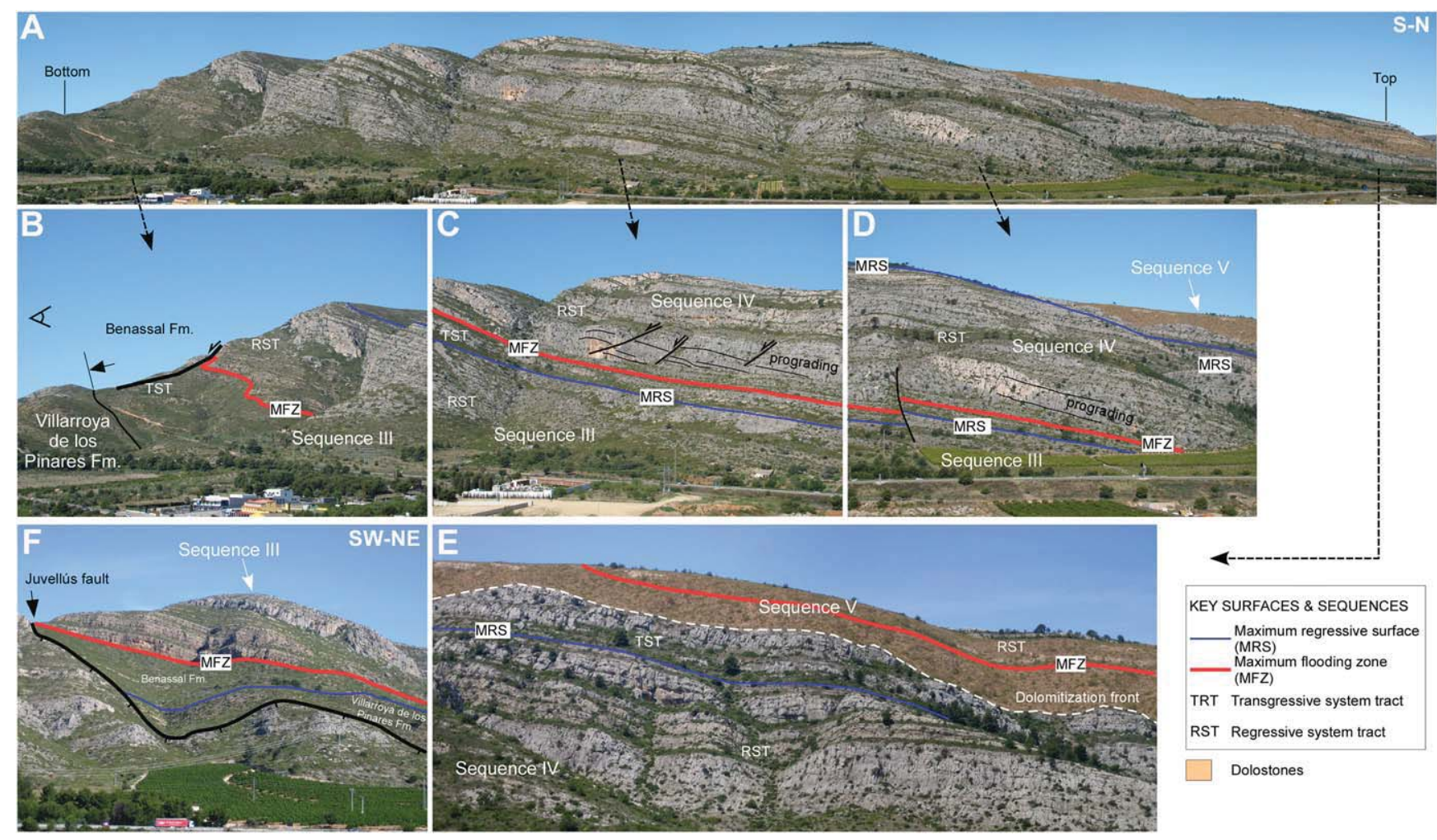

Fig. 7. Field view of the Orpesa Range showing: (A) the continuous outcrop of the Early Aptian to Albian Benassal Formation. The complete outcrop is 4 km long; (B-E) partial views of image A with sequence stratigraphy interpretation; (F) field view of the basal Racó de Rita section and the trace of the Juvellús fault. Note the boundary between the Villarroya de los Pinares and Benassal Fm and the outcrop of the dolomite cemented cross-bedded grainstones (LFT2) in the footwall block. The point of view is noted in image B.

\subsubsection{Dolostone petrography}

At the outcrop scale, the dolostone ranges in colour from brown to grey, and is typically orange when partially calcitized. In fresh rock samples the dolostone is dominantly grey coloured. The bulk of the dolostone (up to $70 \%$ ) is a replacive dolomite that forms very tight crystal mosaics with low intercrystalline porosity (Fig. 12A-D). Dolomite is present as transitional planar-s to nonplanar-a crystals with cloudy appearance (inclusion-rich) and polymodal size distribution. Most of the replacive mass is fine to coarse crystalline $(50-600 \mu \mathrm{m})$, showing a light grey colour under plane polarized light and dominant undulose extinction under crossed light. Dolomite crystals are ferroan to slightly ferroan as indicated by the staining with Kferricyanide. The replacive dolomite mosaics exhibit scattered sub-millimetric intercrystalline pores and millimetre vuggy pores (Fig. 12A-C).

The dolomite pervasively replaces matrix, grains, and early calcite cements in grain-dominated fabrics and, less frequently, in micrite-dominated fabrics (Fig. 12A-C). It replaces bioclastic wackestones to packstones (LTF11) and peloidal grainstones (LTF3). The replacement of the host limestone is mainly fabric-retentive (mimetic), as allochems (peloids and ooids) and biochems (foraminifera, coralline algae and other bioclasts) are easily distinguishable in thin section. Petrological evidence of the original limestone fabrics is also indicated by the presence of: (i) moldic porosity between the dolomite crystal mosaics, which denotes the dissolution of bioclastic components; (ii) non-dolomitized glauconite grains, which indicate the replacement of grain-dominated facies; (ii) dolostone with homogeneous crystal mosaics without preserved fabrics, which are interpreted to replace fine-grained micrite-rich facies.

\subsubsection{Hosted ore deposits}

Locally, the dolomitized intervals of the Benassal Fm host Mississippi Valley Type ( $\mathrm{Pb}-\mathrm{Zn}-\mathrm{Ba})$ mineral deposits and $\mathrm{Fe}-$ oxide mineralizations. The MVT deposits (Font d'en Campello mine) appear in a fractured and brecciated karst system located in the Campello fault zone (Fig. 3). Saddle dolomite, calcite cement, galena, sphalerite and barite partially cement fractures and karst infillings. Saddle dolomite filling fractures occur as large-sized crystals that overgrowth the matrix replacive dolomite, whereas calcite cement and MVT mineralization fills the remaining porespace (Fig. 12D). The karst infillings are laminated and composed of sand-sized quartz and mica, dolomitized and nondolomitized host limestone clasts, and fine insoluble residues (clay minerals and Fe-oxides). Quartz and mica are characteristic of the uppermost limestone beds suggesting that the karst and the MVT mineralization are located very close to the top of the Benassal Fm. In addition to the MVT deposits, iron-oxide mineralizations occur at the Mortorum Hill, where old and abandoned trenches and dumps provide physical evidence of mining activities (Fig. 11E).

\section{Discussion}

\subsection{Age of the Benassal Fm}

The age of the sedimentary succession was partially calibrated by means of ammonite specimens collected in the Benassal Fm and in the underlying Forcall Fm (Moreno-Bedmar et al., 2009b, 2010) (Figs. 9 and 13). The Dufrenoyia furcata ammonite biozone occurs in the Forcall Fm confirming the Early Aptian age typically reported from other localities within the Maestrat Basin (Martínez et al., 


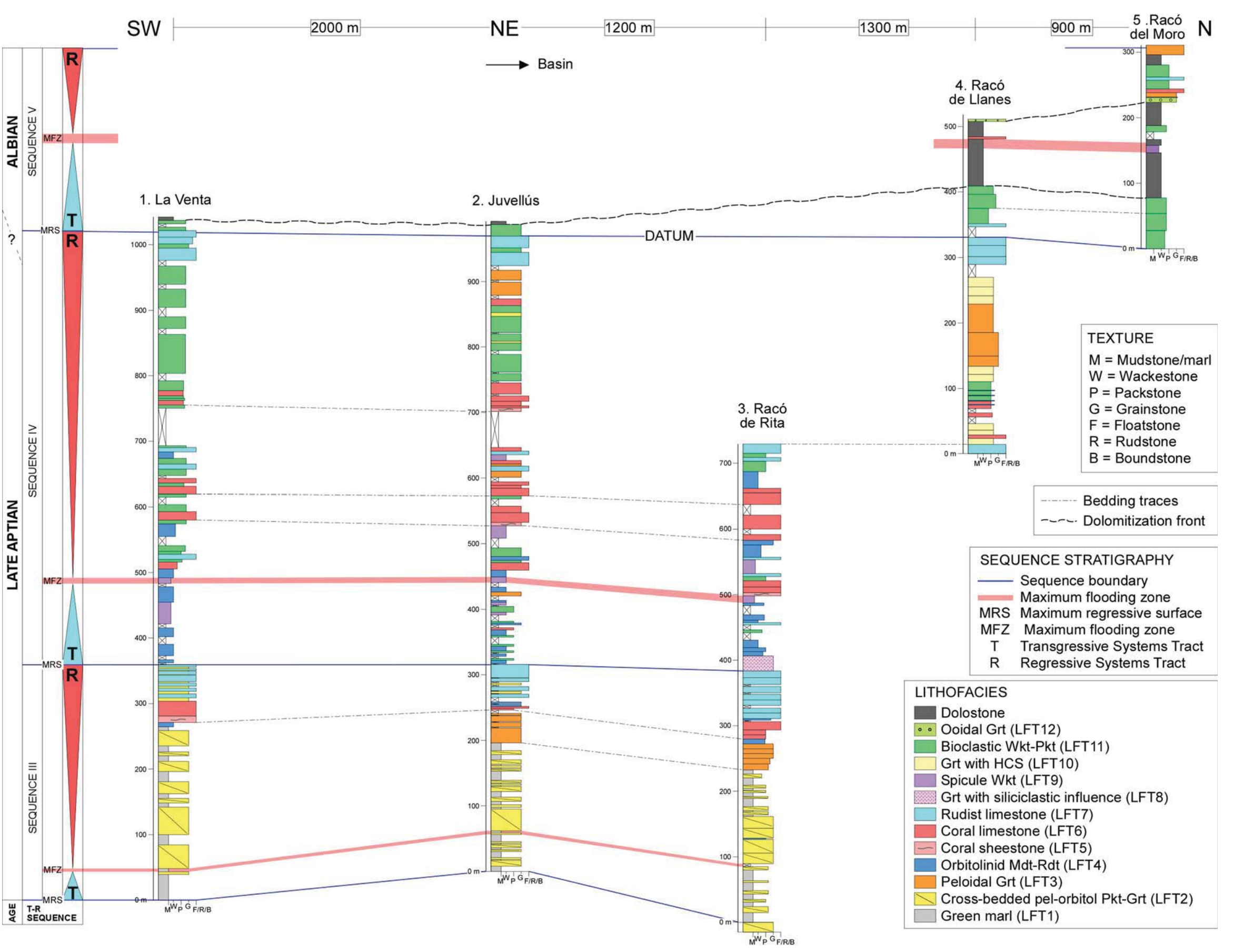

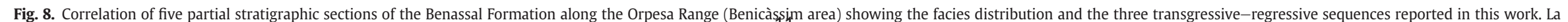
Venta and Juvellús sections redrawn after Tomás et al. (2008) and Comas (2006) respectively. Textural classification sensu Embry and Klovan (1971). See Fig. 3 for section location. 


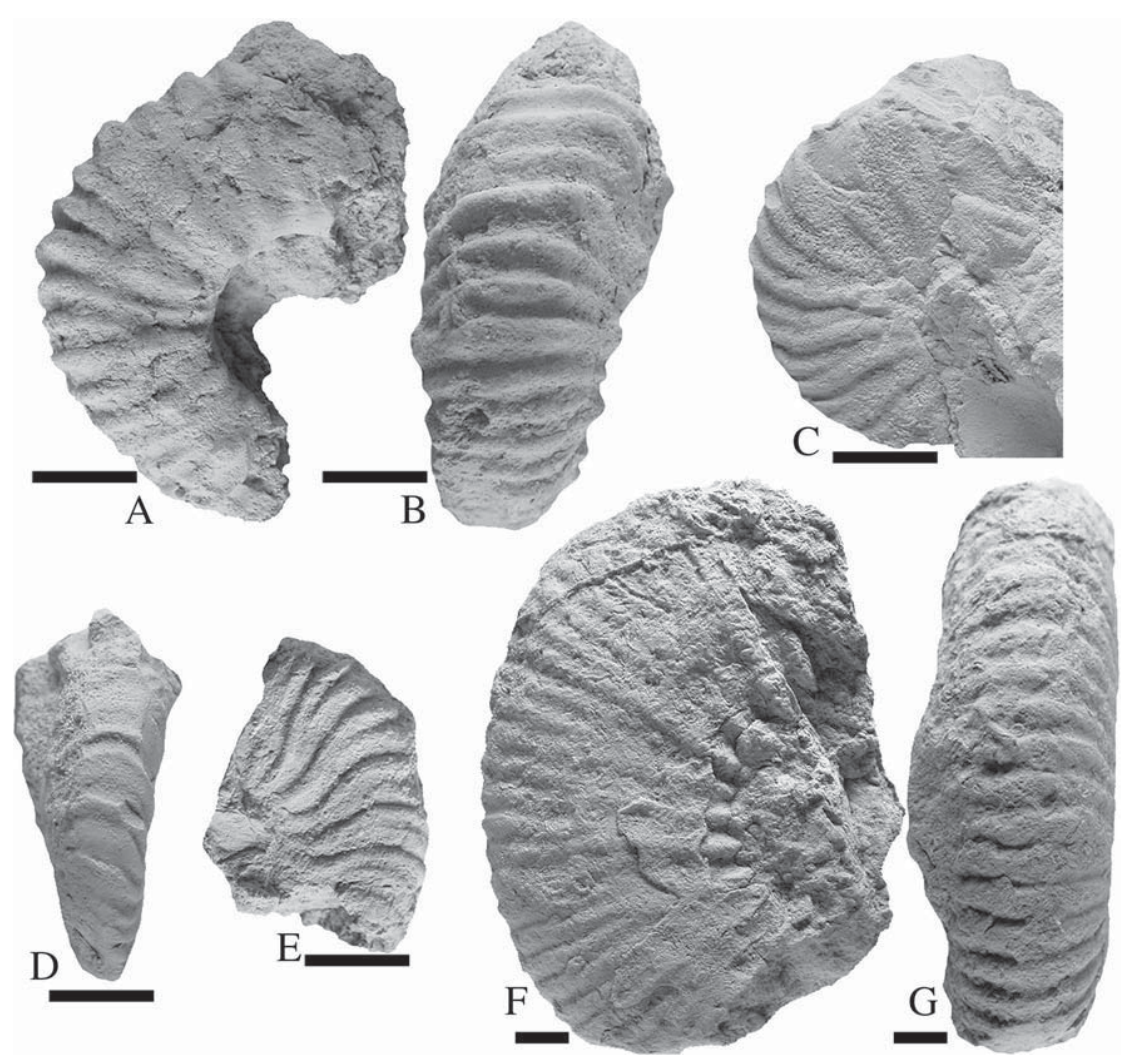

Fig. 9. Ammonite specimens collected in the Benicàssim area showing: (A, B) Epicheloniceras sp. lateral and ventral views of the specimen PUAB (Collections of Paleontology of the Universitat Autònoma de Barcelona) 68596; (C, D) Caseyella sp. lateral and ventral views of the specimen PUAB 68593; (E) Caseyella sp. lateral view of the specimen PUAB 68594; (F, G) Parahoplites cf. vectensis lateral and ventral views of the specimen PUAB 68597. Scale Bar $=1 \mathrm{~cm}$.

1994; Bover-Arnal et al., 2009b, 2010; Moreno-Bedmar et al., 2010, 2012).

The ammonites collected at the base of the Benassal Fm allow recognition of the Late Aptian Epicheloniceras martini biozone (Fig. 13). Moreover, the identification of the Epicheloniceras debile subzone (earliest Late Aptian) indicates that the boundary between the Benassal Fm and the underlying Villarroya de los Pinares Fm is located at or close to the limit between the Early and the Late Aptian. The same time boundary between both formations has been reported in the Galve sub-basin (Maestrat Basin) (Bover-Arnal et al., 2009b, 2010). More recently, however, the Dufrenoyia furcata ammonite biozone has been recognized at the base of the Benassal $\mathrm{Fm}$ in the Galve sub-basin indicating that at least in some parts of this sub-basin, the boundary with the underlying Villarroya de los Pinares Fm is Early Aptian in age (Moreno-Bedmar et al., 2012; Bover-Arnal et al., 2011b). The second marly unit of the studied succession recorded the Parahoplites melchioris ammonite biozone, which indicates that the regressive unit of the Sequence III is Late Aptian in age as well (Fig. 13).

The lack of ammonite specimens in Sequences IV and V does not allow a precise dating of the rest of the succession in the Benicàssim area. However, a Late Aptian age has been reported for Sequence IV based on the identification of Simplorbitolina manasi and Simplorbitolina conulus (Neumann, 1987; Tomás, 2007). Accordingly, the Acanthohoplites nolani ammonite zone (Late Aptian) has been identified in the Sequence IV of the Benassal Fm in the Galve subbasin (Bover-Arnal et al., 2009b, 2010). Hence, Sequence V is most likely Late Aptian to Early Albian in age as partly supported by the recognition of the Leymeriella tardefurcata biozone in the base of the overlying Escucha Fm (Moreno-Bedmar et al., 2009a) (Fig. 13).
Preliminary results of an ongoing analysis of the orbitolinid content along the Sequence $\mathrm{V}$ of the studied succession reported the presence of the sub-genus Conicorbitolina, probably Orbitolina conica (Bernaus, pers. commun.). The identification of these orbitolinid taxa indicates that the top of the Benassal Fm (Sequence V) is most probably Late Albian in age in the Benicàssim area. At a basinal scale it will imply that the shallow-marine conditions prevailed in strongly subsiding areas (Benicàssim) whereas continental sedimentation was widespread in most of the basin. This hypothesis, however, should be substantiated by further biostratigraphic data.

\subsection{Depositional system of the Benassal Fm}

The sedimentological analysis and the correlation between sections along the Orpesa Range indicate that the Benassal Fm of the Benicàssim area was deposited in a dominant shallow-marine carbonate ramp environment (Comas, 2006; Tomás, 2007; Tomás et al., 2008). The ramp-type depositional system is supported by the lateral continuity of the facies belts and by the absence of steplike structures or bulged strata (Tucker and Wright, 1990; Burchette and Wright, 1992).

The development of the carbonate platform was controlled by the SW-NE-trending Benicàssim and the W-E-trending Campello normal faults, which form a graben structure tilted towards the $\mathrm{N}$ (Fig. 3). The system prograded towards the E-NE with proximal areas located towards the $\mathrm{W}$ (i.e., footwall block of the Benicàssim fault). Lines of evidence supporting this orientation include: (a) the presence of deeper and/or more open marine facies towards the north; (b) the foresets with large-scale cross-stratification prograding towards the east (Fig. 4B). Hence, the succession 


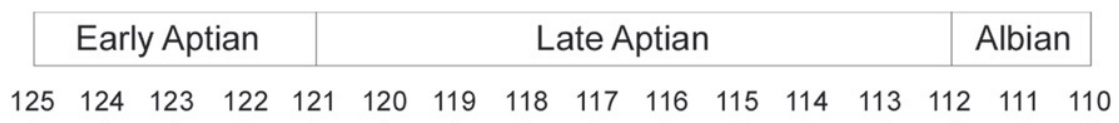

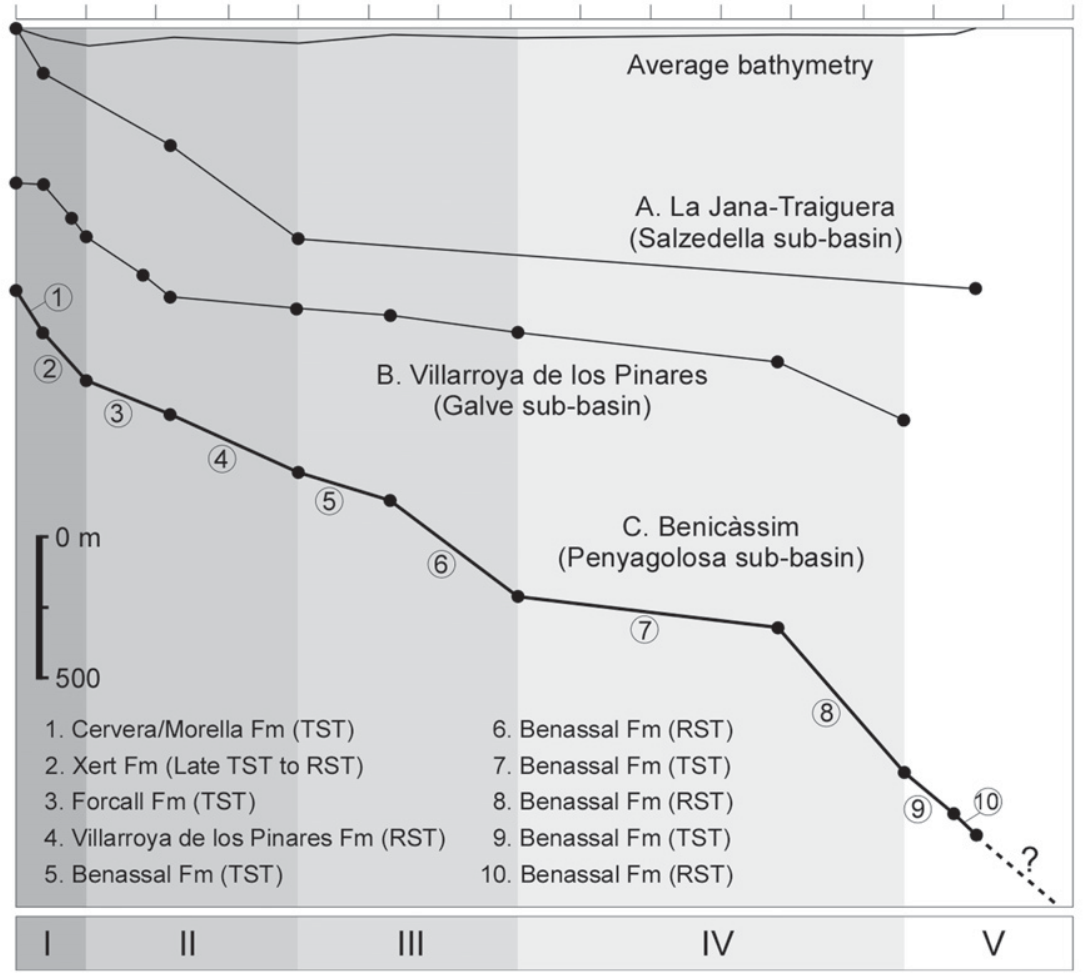

Fig. 10. Decompacted total subsidence curves of the Aptian succession in the Maestrat Basin showing higher rates of accommodation at the Benicàssim area (Penyagolosa subbasin) compared to those at the Galve (Bover-Arnal et al., 2010) and the Salzedella sub-basins (Salas et al., 2001). I-V represent transgressive-regressive (T-R) sequences. Absolute ages are according to Ogg and Ogg (2006) (Modified from Bover-Arnal et al., 2010).

outcropping along the Orpesa Range represents an oblique section of the Benassal Fm platform. The extension of the carbonate platform is unknown due to the overprint of the Neogene extension related to the opening of the València Trough, in the western Mediterranean.

Sequence III (Late Aptian) reflects a sedimentary evolution from basinal settings (TST) to open ramp environments (RST). The transgressive marly deposits located at the lower part of the succession are characteristic of the basal Benassal Fm throughout the Maestrat Basin (Salas et al., 2001). These mixed siliciclasticcarbonate deposits represent the sedimentary response to the generalized sea level rise and drowning of the underlying Early Aptian carbonate platform (Villaroya de los Pinares Fm) (Figs. 7 and 8 ). The bioclastic packstones with sharp erosional basal contact intercalated within the marls most probably represent the product of storm episodes (tempestites). Above the marly unit, the subsequent regressive cross-bedded peloidal and orbitolinid grainstones are interpreted as prograding skeletal banks generated at the ramp to basin transition (e.g., Reid and Dorobek, 1993) (Fig. 4C). The origin of these grainy deposits is most likely associated with basinward transport of proximal ramp material related to sea level fall pulses or syn-rift activity, or even internal waves (see Pomar et al., 2012).

The uppermost part of Sequence III, together with Sequences IV and V (Middle Aptian to Early Albian), were deposited in a shallowmarine carbonate environment characterized by scarce terrigenous influx. The depositional setting was dominated by orbitolinid, coral and rudist bivalves fauna, which characterize the Urgonian-type facies commonly reported from Barremian to Albian successions along the margins of the Tethys Ocean (e.g., García-Mondéjar, 1990; Bover-Arnal et al., 2009b; Embry et al., 2010; Skelton and Gili, 2012) (Fig. 8).

Orbitolinids constitute an important skeletal component in most of the reported lithofacies although are especially abundant in LFT2 and LFT4 (Table 1). Occasionally, the orbitolinids appear in high-density populations in LFT4 suggesting physical reworking (Fig. 4E). Similar facies have been attributed to a great variety of depositional environments in the literature (e.g., Pittet et al., 2002; Hillgärtner et al., 2003; Bover-Arnal et al., 2011b). In agreement with Vilas et al. (1995), the reported orbitolinid-rich facies are dominant in the transgressive deposits of Sequences III and IV (Fig. 8), which is probably associated with higher siliciclastic influx. In this regard, orbitolinid-rich mixed siliciclastic-carbonate stratigraphic intervals are common constituents of transgressive Aptian successions in the Tethyan realm (e.g., Pittet et al., 2002; BoverArnal et al., 2010; Embry et al., 2010; Stein et al., 2012).

In the study area, the transgressive orbitolinid-bearing deposits frequently pass upwards to low-energy coral-bearing micritic limestones (LFT5 and LFT6). This occurs in the RST of Sequences III and IV (Fig. 8). Based on the analysis of the coral assemblages from La Venta section (Sequence III) by Tomás et al. (2008), the coral communities were interpreted as being characteristic of low-light, outer to middle ramp environments. The corals display an unbound growth fabric and are embedded in a dominant micritic texture. Non-reef building coral populations have been recently studied in the western Maestrat Basin by Bover-Arnal et al. (2012).

Towards the top of Sequence IV, the lithofacies reflect storminfluenced middle ramp settings (e.g. Burchette and Wright, 

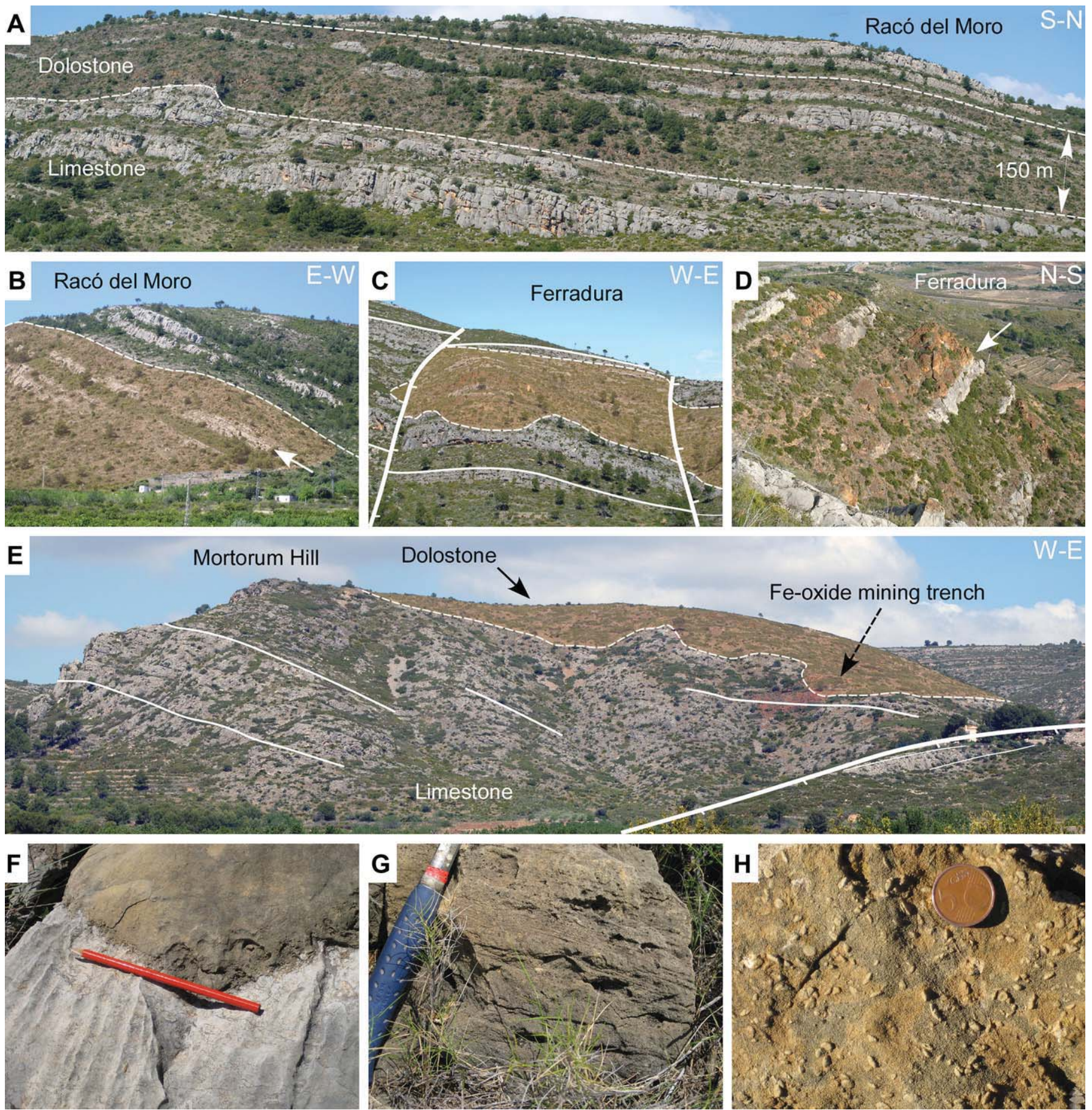

Dolostone

W-E

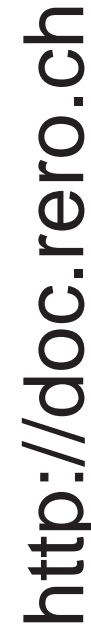

Fig. 11. Field views of the Benassal Fm in the Benicàssim area showing: (A) Stratabound dolostones (brown colour) within the host limestones (grey colour) at the Racó del Moro site; (B) Lateral view of image A (right margin) with 3D outcropping. Note the occurrence of unreplaced limestone beds (floating?) within the dolostone body (arrow). (C) Close relationship between dolostone bodies and faults in La Ferradura site. (D) Close view of C (left margin) showing metre-scale dolostone bodies, and sharp and straight dolomitizing fronts. (E) Stratabound dolomitizing front (dashed line) at the Mortorum Hill. (F) Typical dolomitizing front showing sharp and wavy boundary between dolostone and limestone (pencil is $15 \mathrm{~cm}$ long). ( $\mathrm{G}$ and $\mathrm{H}$ ) Close view of the dolostone with preserved cross-bedding and bioclastic components (orbitolinids) respectively. See Fig. 3 for outcrop location. (For interpretation of the references to colour in this figure legend, the reader is referred to the web version of this article.)

1992; Mohseni and Al-Aasm, 2004). The storm influence is highlighted by the presence of hummocky cross-stratification (HCS), graded beds and shell lags (Fig. 6A, B). The rudist-bearing facies of Sequences III and IV distinguish a platform top setting (Fig. 8). These lithofacies, which dominantly exhibit micritic fabrics, have been interpreted as inner ramp environment deposits (Tomás et al., 2008). However, the variety of rudist taxa and associated rock textures observed most probably represent diverse environments ranging from inner to outer ramp settings (e.g., Alsharhan \& Nairn, 1993; Hillgärtner et al., 2003; Masse et al., 2007; Embry et al., 2010; Masse and Fenerci-Masse, 2011; Skelton and Gili, 2012). An inner ramp environment is commonly supported by the association of rudists with Chondrodonta bivalves and nerineid gastropods (Hartshorne, 1989; Embry et al., 2010; Ayoub-Hannaa and Fürsich, 

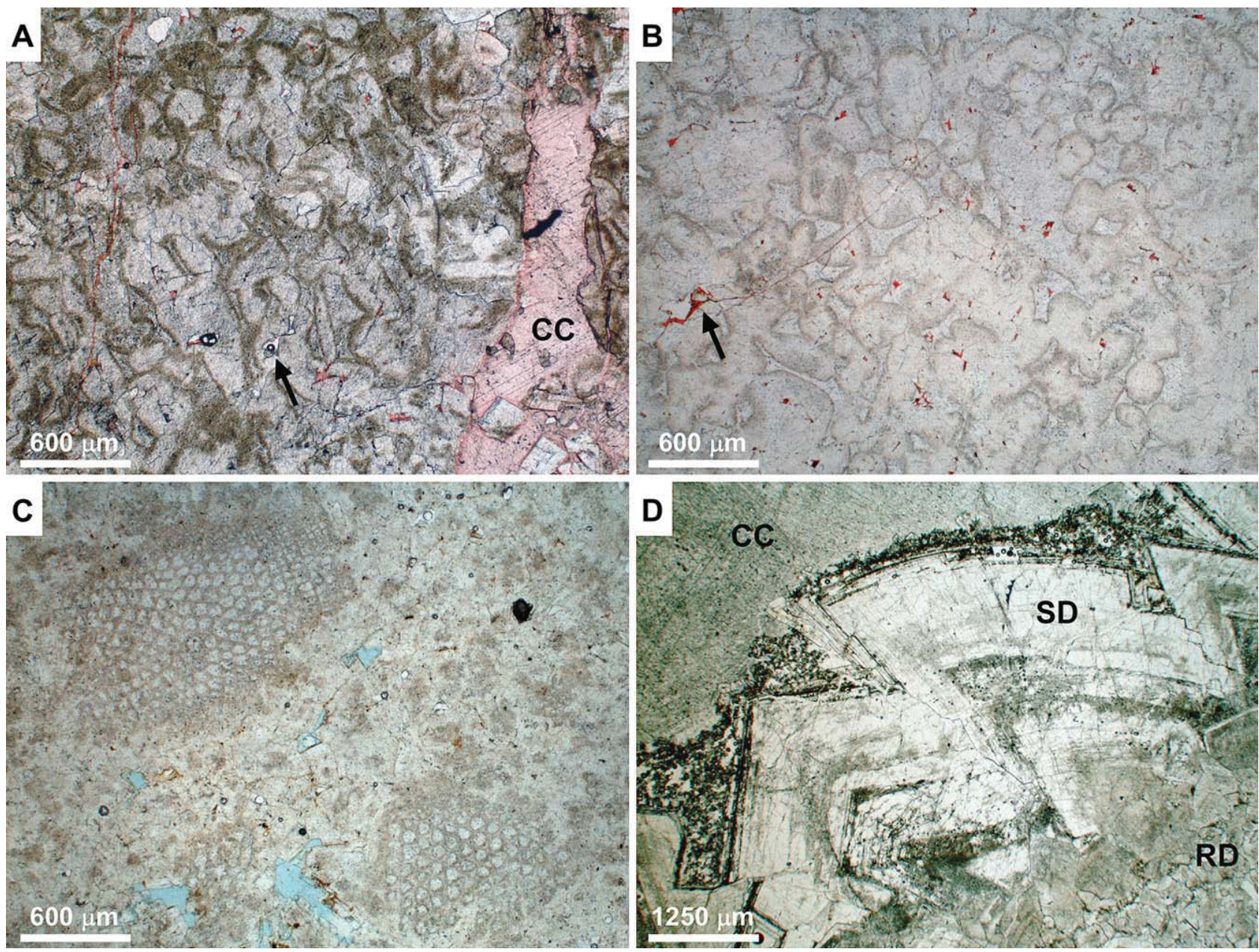

Fig. 12. Photomicrographs of dolomite textures. (A) Replacive dolomite crystal mosaic showing planar-s textures and low intercrystalline porosity (arrowed). Calcite appears in red colour after staining with Alizarin Red-S. (B) Diffused light image of a replacive dolomite crystal mosaic showing ghosts of the original grain components. Note the calcite cement (Stained with Alizarin Red-S) filling intercrystal and fracture (arrowed) porosity. (C) Diffused light image of a replacive dolomite crystal mosaic showing ghosts of the orbitolinids of the original texture, which is most likely a wackestone to packstone. (D) Replacive dolomite crystal mosaic (RD) overgrowth by saddle dolomite (SD), both postdated by late calcite cement (CC). (For interpretation of the references to colour in this figure legend, the reader is referred to the web version of this article.)

2011). The reported rudist taxa register the radiation of radiolitids and polyconitids that, together with the ubiquitous requieniids, dominated the carbonate platforms of the northern Tethys during the Late Aptian (Fenerci-Masse et al., 2006; Skelton and Gili, 2012).

The coral- and rudist-bearing deposits typical of Sequences III and IV are absent in Sequence V (Albian). Although partially masked by the extensive dolomitization, the transgressive deposits are interpreted to represent middle to outer ramp environments. The proposed depositional model is supported by the presence of bioclastic wackestones to packestones evolving upwards to sponge spicules-rich deposits. The bioclastic facies are occasionally topped by skeletal sands and biostromes of rudist and Chondrodonta bivalves, probably occupying the transition to the inner ramp (margin). The regressive deposits represent outer to inner ramp environments. The occurrence of ooidal grainstones suggests a partial protection by subtidal shoals of the inner ramp environment.

\subsection{Syn-rift subsidence and accommodation}

A quantitative estimation of the accommodation was obtained after correcting the total subsidence with estimated palaeobathymetries following the procedure reported in Vilas et al. (2003). The considerable thickness of the Early Cretaceous succession of the Benicàssim area, specifically by the Benassal Fm compared to age-equivalent successions elsewhere in the Maestrat Basin, indicates that fault-induced subsidence was the most important mechanism that created accommodation space during the Aptian and earliest Albian times. Accommodation is largely attributed to the tectonic activity of the Campello and Benicàssim extensional faults during the Early Cretaceous synrift deposition. This is indicated by the thickness distribution of the Benassal Fm showing thicker successions in the hanging wall of both faults (Nebot, 2011). Moreover, the presence of frequent fossilized syn-sedimentary faults implies a high rift activity during the Late Aptian (Fig. 7). The variation in thickness of the Early Cretaceous succession across syn-rift faulted blocks is widely recorded at the basin-scale (Antolín-Tomás et al., 2007; Bover-Arnal et al., 2009b; Embry et al., 2010; Salas et al., 2001).

Even though the Aptian is considered an overall syn-rift time period in the Maestrat Basin (Salas et al., 2001), the detailed analysis of its sedimentary record highlights the occurrence of stages of rapid and slow subsidence. The total subsidence curve of the Benicàssim area (Penyagolosa sub-basin) displays similar trends as 


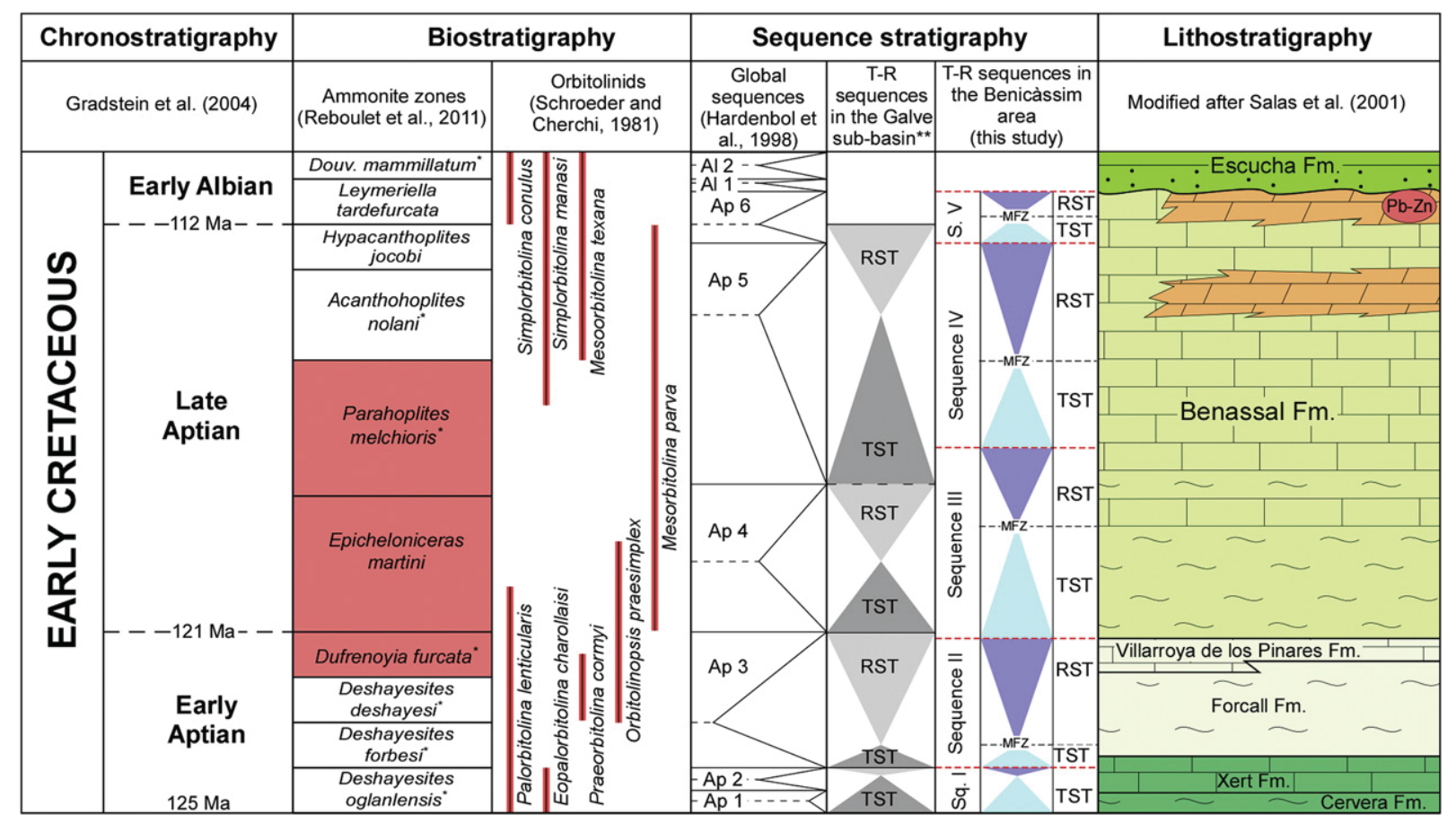

Fig. 13. Chrono-, bio-, sequence- and lithostratigraphic chart showing most important reported data of the Lower Cretaceous deposits in the Benicàssim area. The ammonite and orbitolinid biozones identified in the succession are shaded in red. Ammonites identified elsewhere in the Maestrat Basin are represented with * (Martínez et al., 1994; MorenoBedmar et al., 2010). ** Bover-Arnal et al. (2009b). Dashed lines in T-R sequences indicate lack of absolute dating. (For interpretation of the references to colour in this figure legend, the reader is referred to the web version of this article.)

the time-equivalent ones measured in parts of the Basin such as the Salzedella sub-basin (Salas et al., 2001) and the Galve sub-basin (Bover-Arnal et al., 2010) (Fig. 10). The Aptian in the Maestrat Basin was characterized by an initial and short stage of rapid subsidence ( $T-R$ Sequence I) followed by a longer stage of lower subsidence rate (Sequences II and III). This behaviour suggests a relatively homogenous syn-rift activity along the Basin during the Early to Middle Aptian. In addition to tectonic activity, creation of accommodation was favoured by periods of eustatic sea level rise that led to the deposition of basinal marls. This was the case during the Lower Aptian Sequence II (Forcall Fm) and the Upper Aptian Sequence III (lower Benassal Fm).

After the earliest Late Aptian, the rate of subsidence kept constant in both the Salzedella sub-basin and the Galve sub-basin (Fig. 10). By contrast, higher rates of total subsidence are recorded in the Benicàssim area (Penyagolosa sub-basin), where a pulse of rapid subsidence took place during the Late Aptian to Early Albian (RST of Sequence IV and Sequence V).

Despite the strong evidence of syn-rift activity, the three sequences identified in the Benassal Fm of the Benicàssim area are correlatable with the Late Aptian global sequences of Hardenbol et al. (1998). Therefore, a partial control by eustasy in the accommodation cannot be ruled out. A more precise dating of the sequences recognized is needed to constrain the tectonic vs globalscale eustasy influence in the reported sequences.

\subsection{Carbonate vs coarse siliciclastic deposition}

Very sparse coarse siliciclastic deposits are recorded in the Benassal Fm despite the calculated high rates of subsidence. This low siliciclastic input may be the result of: (a) the lack of proximal emerged areas; (b) the presence of local topographic highs acting as barriers for inland-derived sediments; and (c) the occurrence of an isolated carbonate system developed in the upthrown fault block (i.e., not attached to the continent).

The location of the studied successions in the eastern part of the Maestrat Basin is relatively far away from the regional clastic source areas located in central and western Iberia (Caja et al., 2007). By contrast, significant siliciclastic inputs are recorded in the Aptian succession of the western margin of the Maestrat Basin (Galve subbasin) due to its closer location from the aforementioned provenance areas (Bover-Arnal et al., 2009b, 2010, 2011a; Embry et al., 2010). However, the most important factor controlling the coarse siliciclastic input in the Benicàssim area was probably related to the occurrence of regional topographic highs within the Penyagolosa sub-basin. The Desert de les Palmes range has been reported to have formed a topographic high during the Early Cretaceous (Roca et al., 1994), and was thus the most likely structure preventing the siliciclastic influx to the Benicàssim area.

\subsection{Fault controls on stratabound dolomitization}

Detailed mapping of individual dolostone geobodies shows that they are in close spatial association with Early Cretaceous normal faults (Campello and Benicàssim faults) suggesting a faultcontrolled dolomitization process (Fig. 3). Most of the dolostone bodies are located in the hanging wall blocks, which is a common characteristic of structurally controlled dolostones (Davies and Smith, 2006; Machel, 2004; Warren, 2000). Field observations indicate that the Campello and Benicàssim faults reach kilometrescale stratigraphic offsets, and thus they are seismic-scale and probably affect the Palaeozoic basement. Dolostones decrease progressively towards the SW away from the Campello Fault, and thus the latter is interpreted to have been the most important feeding point for dolomitizing fluids. This is supported by the location of the MVT mineralization along the trace of the Campello Fault. However, the location of some individual dolostone bodies in 
the southwest of the study area (i.e., far away from the Campello Fault) strongly suggests the role of the Benicàssim Fault as a complementary fluid conduit for fluids. A primary control of the fault system in the replacement of the Benassal Fm host limestones is supported by the increase in dolomite and calcite cement in the vicinity of faults and fractures.

The association of the dolostones and the MVT deposits with the same fault indicate that it represented a common conduit that channelled successive dolomitizing and mineralizing fluids (Martín-Martín et al., 2012). Similar relationships between faults and MVT deposits are typically reported from burial dolostones worldwide (Davies and Smith, 2006; Gregg, 2004; Machel, 2004; Warren, 2000). In the Benicàssim area, however, the precise geometry of the dolostone bodies (stratabound vs non-stratabound) in the fault zones is not fully recognized due to the structural overprinting by the Neogene extension (i.e., the dolostone bodies are offset). The clays of the Escucha Fm, which overlay the Benassal Fm, may have helped the dolomitizing fluids to flow laterally along most permeable beds of the host limestones (i.e., top seal).

Additionally, field and analytical data indicate that dolomitization was partially controlled by the host rock depositional fabric (facies) and the pre-dolomitization diagenetic alteration. A partial control of depositional facies on the replacement is supported by the presence of non-replaced limestone beds located between the main dolostone body in the Racó del Moro, which are constituted by very tight (i.e., low-porosity) mudstones and wackestones (Fig. 11). A facies influence on the replacement is supported by the presence of sharp dolomitization fronts perfectly following the bedding (see Machel, 2004) (Fig. 11). In addition, early calcite and dolomite cementation occluded most of the primary porosity in the non-replaced grain-dominated facies (Fig. 6D), probably preventing or limiting the circulation of dolomitizing fluids during the replacement stage. A strong local variability in early calcite cement distribution, and thus in porosity and permeability patterns, is suggested by highly calcite cemented limestone beds that are laterally dolomitized.

\subsection{Timing and temperature of dolomitization}

Petrographic observations of dolostones indicate that the replacement of the host limestone is postdated by the MVT mineralization. The MVT deposits of the Benicàssim area most likely formed during the Early Paleocene, which corresponds to the absolute model age $(\mathrm{U}-\mathrm{Pb})$ of an ore-stage calcite associated with MVT deposits elsewhere in the Maestrat Basin (62.5 Ma; Grandia et al., 2000). Therefore, dolomitization is assumed to have occurred between the Late Albian and the Early Paleocene, most probably during the Late Cretaceous post-rift stage of the Maestrat Basin following Salas et al. (2001). Accordingly, preserved fabrics in replacive dolomites demonstrate that dolomitization took place after early calcite cementation, mechanical compaction, and early stages of fracturing, and hence, during burial. An early dolomitization process overprinted by later burial hydrothermal fluids is mostly ruled out due to the lack of petrographic data supporting this hypothesis.

The presence of dolostone bodies spatially associated with faults and showing sharp boundaries with the country host rocks is commonly attributed to high-temperature replacement processes (Allan and Wiggins, 1993; Davies and Smith, 2006; Duggan et al., 2001; Machel, 2004; Wilson et al., 2007; Warren, 2000). A hightemperature dolomitization is supported by the presence of replacive dolomites with non-planar textures, which are commonly interpreted to result from temperatures exceeding $60^{\circ} \mathrm{C}$ (Gregg and Sibley, 1984). Additional data indicating a high-temperature process are: (i) the presence of saddle dolomite (Machel, 2004;
Warren, 2000), and (ii) the association with MVT mineralization (Gregg, 2004). Fluid inclusion data from saddle dolomites worldwide reported in the literature yielded temperatures above $80^{\circ} \mathrm{C}$ in all cases (Spötl and Piman, 1998), and thus this temperature is regarded as the minimum temperature of saddle dolomite formation in the study area. Accordingly, microthermometry data from fluid inclusions in ore-bearing calcite associated with MVT deposits elsewhere in the Maestrat Basin yielded temperatures about $140{ }^{\circ} \mathrm{C}$ (Grandia, 2001).

Quantitative subsidence analysis indicate that the dolomitization of the Benassal Fm carbonates occurred at burial depths $<1000 \mathrm{~m}$, and thus by hydrothermal fluids (Gomez-Rivas et al., 2010; Martín-Martín et al., 2010). The geothermal gradient during the Early Cretaceous rifting in the Maestrat Basin was calculated to be $30-35^{\circ} \mathrm{C} / \mathrm{km}$ (Caja et al., 2009), and thus the maximum temperature reached by the dolomitized host rock due to rift activity was most likely below $\sim 60^{\circ} \mathrm{C}$. Alternatively, the most likely origin of the heat flow necessary for the replacement of the Benassal Fm could be related to a middle Cretaceous regional thermal event (Salas et al., 2005). This event was proposed based on the occurrence of several coeval high-temperature phenomena in areas close to Benicàssim during the Late Cretaceous post-rift stage. Among others, such phenomena include (Fig. 2): (a) Low-grade metamorphic conditions $\left(\sim 300^{\circ} \mathrm{C}\right)$ recorded in the Permo-Triassic red beds dated between $\sim 107 \pm 2$ (Albian) and $\sim 93 \pm 2$ Ma (Cenomanian) (Martín-Martín, 2004; Martín-Martín et al., 2009), and (b) Hydrothermal dolomitization $\left(\sim 240^{\circ} \mathrm{C}\right)$ associated with $\mathrm{Hg}$ bearing veins dated as $\sim 84-85 \mathrm{Ma}$ (Santonian) (Tritlla and Cardellach, 1997; Tritlla and Solé, 1999).

\section{Conclusions}

The Upper Aptian to Lower Albian Benassal Fm of the Benicàssim area (Maestrat Basin) was deposited in a syn-rift graben structure bounded by Early Cretaceous seismic-scale basement faults. The succession is up to 1500 -m-thick, constituting one of the most complete shallow-marine carbonate records of this age in the Tethyan realm. The lithofacies are mainly characterized by the presence of orbitolinid foraminifera, coral and rudist bivalve fauna. A carbonate ramp depositional environment was inferred based on the lateral continuity of the carbonate facies, and by the absence of step-like structures or bulged strata.

The Benassal Fm is stacked in three transgressive-regressive ( $\mathrm{T}-\mathrm{R}$ ) sequences (410-, 710-, and 380-m-thick respectively) bounded by surfaces with sequence stratigraphic significance. The third sequence, which is Late Aptian to Early Albian in age, is reported for the first time in the Maestrat basin. The total subsidence curve during the Aptian (Penyagolosa sub-basin) is comparable to timeequivalent curves in other sub-basins. The analysis of the Benicàssim subsidence curve shows a fast rate of subsidence during the onset of the Aptian followed by slower rates of subsidence during the Early to Late Aptian times.

Field data indicate that the dolomitization of the Benassal Fm took place in an extensional tectonic setting, most probably during the Late Cretaceous post-rift stage of the Maestrat Basin. The dolostones are mainly in hanging wall blocks, forming seismicscale stratabound tabular geobodies that extend several kilometres away from the fault zone. Field and petrological data indicate that middle to inner ramp grain-dominated facies were preferentially replaced. These facies are dominated by bioclastic-peloidal packstones and peloidal grainstones from the third sequence of the Benassal Fm. The dolostone registers the typical hydrothermal paragenesis constituted by the host limestone replacement, dolomite cementation, and sulfide MVT mineralization. 
Results suggest that, together with the primary control of the fault system as conduits for dolomitization and mineralization, the depositional facies and the early diagenetic alterations partially controlled the replacement of the host limestones. This is indicated by the presence of non-replaced micrite-dominated limestone beds intercalated within the dolostone bodies and grain-dominated beds highly cemented by calcite next to the dolomitization fronts. These low-porosity facies may have enhanced the lateral flow and thus the stratabound geometry of the dolostones away from the feeding points (i.e., faults).

The present study provides a stratigraphic framework that can be used for oil exploration in age-equivalent sequences worldwide, especially in the nearby València Trough offshore Spain (Western Mediterranean Basin). Moreover, it represents a new case study of fault-controlled dolostones, and thus an outcrop analogue for stratabound dolomitized limestone sequences, especially interesting for equivalent dolomite reservoirs in Middle East and North America. Among others, the study of this outcrop analogue may contribute to reservoir quality prediction by (1) characterizing the spatial relationship between dolostone geobodies and fault networks; (2) documenting variation (enhancement/degradation) in reservoir quality away from faults; (3) contributing to new conceptual ideas for the formation of fault-associated dolostones, and (4) providing outcrop "groundtruthing" for predictive diagenesis tools.

\section{Acknowledgements}

ExxonMobil Production Company and ExxonMobil Upstream Research Company are acknowledged for providing funding to develop this research. We would like to thank all company and faculty $(\mathrm{FC})^{2}$ members for suggestions during group meetings. Special thanks go to Susan Agar for its technical assistance and support since the early stage of the project. J.M. Bernaus is acknowledged for the preliminary analysis of orbitolinids. This research was partially funded by the Spanish Government $(\mathrm{I}+\mathrm{D}+\mathrm{i}$ research projects CGL2008-04916 and CGL2010-18260), the Consolider-Ingenio 2010 programme, under CSD 2006-0004 "TopoIberia", and the Grup Consolidat de Recerca "Geologia Sedimentària" (2009SGR-1451). Finally, the authors would like to thank Cretaceous Research Associate Editor David J. Horne, and P.W. Skelton and M. Aurell for helpful comments that greatly improved the manuscript.

\section{References}

Allan, J.R., Wiggins, W.D., 1993. Dolomite Reservoirs. Geochemical techniques for evaluating origin and distribution, American Association of Petroleum Geologists Continuing Education Course Note Series 36. AAPG, Tulsa (OK).

Allen, P.A., Allen, J.R., 1990. Basin analysis: principles and applications. Blackwell Science, Oxford.

Alsharhan, A., Nairn, A., 1993. Carbonate platform models of Arabian Cretaceous reservoirs. In: Simó, J.A.T., Scott, R.W., Masse, J.P. (Eds.), Cretaceous Carbonate Platforms. American Association of Petroleum Geologists Memoir 56, Tulsa (OK), pp. 173-184.

Antolín-Tomás, B., Liesa, C.L., Casas, A.M., Gil-Peña, I., 2007. Geometry of fracturing linked to extension and basin formation in the Maestrazgo basin (Eastern Iberian Chain, Spain). Revista de la Sociedad Geológica de España 20 (3-4) $351-365$.

Ayoub-Hannaa, W., Fürsich, F.T., 2011. Functional morphology and taphonomy of Cenomanian (Cretaceous) oysters from the eastern Sinai Peninsula, Egypt Palaeobiodiversity and Palaeoenvironments 91 (3), 197-214.

Bond, G.C., Kominz, M.A., 1984. Construction of tectonic subsidence curves for the early Paleozoic miogeocline, southern Canadian Rocky Mountains: implications for subsidence mechanisms, age of break-up, and crustal thinning. Geological Society of America Bulletin 95, 155-173.

Bover-Arnal, T., Martín-Martín, J.D., Gomez-Rivas, E., Travé, A., Salas, R., MorenoBedmar, J.A., Tomás, S., 2009a. Insights into the Upper Aptian carbonate succession of the South-Eastern Maestrat basin (E Iberia). In: Amorosi, A. (Ed.), 27th IAS Meeting of Sedimentologists. Monduzzi Editore, International Proceedings, Pianoro (Bologna), pp. 123-128.

Bover-Arnal, T., Salas, R., Moreno-Bedmar, J.A., Bitzer, K., 2009b. Sequence stratig raphy and architecture of a late Early-Middle Aptian carbonate platform succession from the western Maestrat Basin (Iberian Chain, Spain). Sedimentary Geology 219. 280-231.

Bover-Arnal, T., Moreno-Bedmar, J.A., Salas, R., Skelton, P.W., Bitzer, K., Gili, E., 2010 Sedimentary evolution of an Aptian syn-rift carbonate system (Maestrat Basin, E Spain): effects of accommodation and environmental change. Geologica Acta 8 (3), 249-280.

Bover-Arnal, T., Salas, R., Martín-Closas, C., Schlagintweit, F., Moreno-Bedmar, J.A 2011a. Expression of an Oceanic Anoxic Event in a neritic setting: Lower Aptian coral rubble deposits from the western Maestrat Basin (Iberian Chain, Spain). Palaios 26, 18-32.

Bover-Arnal, T. Salas, R, Skelton, P.W, Gili, E, Moreno-Bedmar, J.A, 2011b. The Aptian carbonate platforms of the western Maestrat Basin: a textbook example of four systems tract-based sequence stratigraphy. In: Arenas, C., Pomar, L. Colombo, F. (Eds.), Pre-Meeting Field Trips Guidebook, 28th IAS Meeting. Sociedad Geológica de España, Zaragoza, pp. 11-26.

Bover-Arnal, T., Löser, H., Moreno-Bedmar, J.A., Salas, R., Strasser, A., 2012. Corals on the slope (Aptian, Maestrat Basin, Spain). Cretaceous Research 37, 43-64.

Burchette, T.P., Wright, P., 1992. Carbonate ramp depositional systems. Sedimentary Geology 79, 311-338.

Caja, M.A., Marfil, R., Lago, M., Salas, R., Ramseyer, K., 2007. Provenance discrimination of Lower Cretaceous synrift sandstones (eastern Iberian Chain, Spain): constraints from detrital modes, heavy minerals, and geochemistry. In: Arribas, J., Critelli, S., Johnsson, M.J. (Eds.), Sedimentary provenance and petrogenesis: perspectives from petrography and geochemistry. Geological Society of America Special Paper 420, pp. 181-197.

Caja, M.A., Salas, R., Marfil, R., Permanyer, A., 2009. Paleothermal constraints from diagenetic minerals recording high temperature conditions in a rift basin (Maestrat Basin, Iberian Range). Journal of Geochemical Exploration 101, 18.

Canerot, J., Cugny, P., Pardo, G., Salas, R., Villena, J., 1982. El Cretácico de España. Universidad Complutense de Madrid, Madrid.

Catuneanu, O., Abreu, V., Bhattacharya, J.P., Blum, M.D., Dalrymple, R.W. Eriksson, P.G., Fielding, C.R., Fisher, W.L., Galloway, W.E., Gibling, M.R., Giles, K.A., Holbrook, J.M., Jordan, R., Kendall, C.G.St.C., Macurda, B., Martinsen, O.J., Miall, A.D., Neal, J.E., Nummedal, D., Pomar, L., Posamentier, H.W., Pratt, B.R., Sarg, J.F., Shanley, K.W., Steel, R.J., Strasser, A Tucker, M.E., Winker, C., 2009. Towards the standardization of sequence stratigraphy. Earth-Science Reviews 92, 1-33.

Climent-Domenech, A., Bover, T., Caja, M.A., 2007. Evolución sedimentaria y estructural del Cretácico inferior en el sector Benicàssim-Orpesa: Cadena Ibérica oriental. Geogaceta 41, 47-51.

Comas, M., 2006. Estudio estratigráfico, sedimentológico y diagenético de la plataforma carbonatada aptiense superior del sector de Benicàssim-Orpesa. DEA Thesis. Universitat de Barcelona, Barcelona.

Davies, G.R., Smith, L.B.J., 2006. Structurally controlled hydrothermal dolomite reservoir facies: an overview. American Association of Petroleum Geologists Bulletin 90, 1641-1690.

Droste, H., 2010. High resolution seismic stratigraphy of the Shu'aiba and Natih formations in the Sultanate of Oman: implications for Cretaceous epeiric carbonate platform systems. In: van Buchem, F.S.P., Gerdes, K.D., Esteban, M. (Eds.) Mesozoic and Cenozoic Carbonate Systems of the Mediterranean and the Middle East: Stratigraphic and Diagenetic Reference Models. Geological Society Special Publications 329, London, pp. 145-162.

Duggan, J.P., Mountjoy, E.W., Stasiuk, L.D., 2001. Fault-controlled dolomitization at Swan Hills Simonette oil field (Devonian), deep basin west-central Alberta, Canada. Sedimentology 48, 301-323.

Embry, A.F., Klovan, J.E., 1971. A Late Devonian reef tract on Northeastern Banks Island, NWT. Canadian Petroleum Geology Bulletin 19, 730-781.

Embry, J.-C., Vennin, E., van Buchem, F.S.P., Schroeder, R., Pierre, C., Aurell, M., 2010 Sequence stratigraphy and carbon isotope stratigraphy of an Aptian mixed carbonate-siliciclastic platform to basin transition (Galve sub-basin, NE Spain). In: van Buchem, F.S.P., Gerdes, K.D., Esteban, M. (Eds.), Mesozoic and Cenozoic Carbonate Systems of the Mediterranean and the Middle East: Stratigraphic and Diagenetic Reference Models. Geological Society Special Publications 329, London, pp. 113-143.

Fenerci-Masse, M., Masse, J.-P., Arias, C., Vilas, L., 2006. Archaeoradiolites, a new genus from the Upper Aptian of the Mediterranean region and the origin of the rudist family Radiolitidae. Paleontology 49, 769-794.

García-Mondéjar, J., 1990. The Aptian-Albian carbonate episode of the BasqueCantabrian Basin (northern Spain): general characteristics, controls and evolution. In: Tucker, M.E., Wilson, J.L., Crevello, P.D., Sarg, J.F., Read, J.F. (Eds.), Carbonate platform: facies, sequences and evolution, International Association of Sedimentologists Special Publication 9, pp. 437-460.

Gomez-Rivas, E. Corbella, M., Martín-Martín, J.D., Teixell, A., Cardellach, E., 2010. Reactivity of dolomitizing fluids and evaluation of Mg sources in the Benicassim area (Maestrat Basin, E Spain). Society of Petroleum Engineers - 72nd European Association of Geoscientists and Engineers Conference and Exhibition $2010-$ Incorporating SPE EUROPEC 2010 4. 2831-2835.

Gomez-Rivas, E., Warber, K., Kulzer, F., Bons, P.D., Khoehn, D., Martín-Martín, J.D. 2012. Structural evolution of the Benicàssim area (Maestrat basin, NE Spain): insights from fracture and vein analysis. Geogaceta 51, 79-82.

Grandia, F., 2001. Origen, evolució i edat dels fluids associats a les mineralitzacions de $\mathrm{Zn}-\mathrm{Pb}$ en carbonats cretàcics de la Conca del Maestrat (Castelló-Teruel), PhD thesis, Universitat Autònoma de Barcelona, Barcelona.

Grandia, F., Asmerom, Y., Getty, S., Cardellach, E., Canals, A., 2000. U-Pb dating of MVT ore-stage calcite: implications for fluid flow in a Mesozoic extensional 
basin from Iberian Peninsula. Journal of Geochemical Exploration 69-70, 377380.

Grandia, F., Cardellach, E., Canals, A., Banks, D.A., 2003. Geochemistry of the fluids related to epigenetic carbonate-hosted $\mathrm{Zn}-\mathrm{Pb}$ deposits in the Maestrat Basin Eastern Spain: fluid inclusion and isotope $(\mathrm{Cl}, \mathrm{C}, \mathrm{O}, \mathrm{S}, \mathrm{Sr})$ evidence. Economic Geology 98, 933-954.

Gradstein, F.M., Ogg, J.G., Smith, A.G., 2004. A Geologic Time Scale. Cambridge University Press, Cambridge.

Gregg, J.M., 2004. Basin fluid flow, base-metal sulphide mineralization and the development of dolomite petroleum reservoirs. In: Braithwaite, C.J.R. Rizzi, G., Darke, G. (Eds.), The Geometry and Petrogenesis of Dolomite Hydrocarbon Reservoirs. Geological Society Special Publication 235, London, pp. 157-175.

Gregg, J.M., Sibley, D.F., 1984. Epigenic dolomitization and the origin of xenotopic dolomite texture. Journal of Sedimentary Petrology 54, 908-931.

Hardenbol, J., Thierry, J., Farley, M.B., Jacquin, T., de Gracianski, P.C., Vail, P.R., 1998 Mesozoic and Cenozoic sequence Chronostratigraphy framework of European Basins. In: de Graciansky, J., Hardenbol, T., Jacquin, Vail, P.R. (Eds.), Mesozoic and Cenozoic Sequence Stratigraphy of European Basins, SEPM Special Publication Series 60. charts $1-8$

Hartshorne, P., 1989. Facies architecture of a Lower Cretaceous coral-rudist patch reef, Arizona. Cretaceous Research 10, 311-336.

Hillgärtner, H., van Buchem, F.S.P., Gaumet, F., Razin, P., Pittet, B., Grötssch, J. 2003. The Barremian-Aptian evolution of the eastern Arabian carbonate platform margin (Northern Oman). Journal of Sedimentary Research 73 (5), $756-773$

Jones, G.D., Gupta, I., Sonnenthal, E., 2011. Reactive transport models of structurally controlled hydrothermal dolomite: implications for Middle East carbonate reservoirs. 9th Middle East Geosciences Conference, GEO 2010. GeoArabia 16 (2), 194-195.

Koehrer, B.S., Heymann, C., Prousa, F., Aigner, T., 2010. Multiple-scale facies and reservoir quality variations within a dolomite body - outcrop analog study form the Middle Triassic, SW German Basin. Marine and Petroleum Geology 27 386-411.

Liesa, C.L., Simón, J.L., 2009. Evolution of intraplate stress fields under multiple remote compressions: the case of the Iberian Chain (NE Spain). Tectonophysics $474,144-159$

Machel, H.G., 2004. Concepts and models of dolomitization: a critical reappraisal In: Geological Society Special Publication 235, London, pp. 7-63.

Martín-Martín, J.D., 2004. Los minerales de la arcilla del Permo-Triásico de la Cordillera Ibérica oriental: Procedencia y evolucion diagenética, PhD thesis, Universidad Jaume I, Castelló de la Plana.

Martín-Martín, J.D., Gomez-Rivas, E., Travé, A., Salas, R., Vergés, J., 2012. Dolomías controladas por fracturas en carbonatos aptienses de la zona de Benicàssim (SE Cuenca del Maestrat): distribución y características petrográficas. Geogaceta 51, $19-22$.

Martín-Martín, J.D., Salas, R., Gómez-Gras, D., Zwingmann, H., 2009. K/AR isotopic dating of very low-grade metamorphic and late diagenetic conditions during the Mesozoic rifting evolution of the Iberian Chain, Spain. In: Proceedings of the XIV International Clay Conference, Castellaneta Marina, pp. 236.

Martín-Martín, J.D., Sanfelíu, T., Gómez-Gras, D., 2005. Mineralogía de arcillas cerámicas, El Permo-Trías de Castelló. Athenea 13. Publicacions de la Universita Jaume I, Castelló de la Plana.

Martín-Martín, J.D., Travé, A., Gomez-Rivas, E., Sizun, J.P., Salas, R., Gómez-Gras, D. Vergés, J., 2010. Fault-associated dolomites in the Benicàssim area, Maestrat Basin, E. Spain - Macro- to micro-scale fluid flow in carbonates. Society of Petroleum Engineers - 72nd European Association of Geoscientists and Engineers Conference and Exhibition 2010 - Incorporating SPE EUROPEC 20104 2980-2984.

Martínez, R., Grauges, A., Salas, R., 1994. Distribución de los ammonites del Cretá cico inferior de la Cordillera Costera Catalana e Ibérica Oriental. Cuadernos de Geología Ibérica 18, 337-354.

Masse, J.-P., Fenerci-Masse, M., 2011. Drowning discontinuities and stratigraphic correlation in platform carbonates. The late Barremian-early Aptian record of southeast France. Cretaceous Research 32, 659-684.

Masse, J.P., Fenerci-Masse, M., Vilas, L., Arias, C., 2007. Late Aptian-Albian primitive Radiolitidae (bivalves, Hippuritoidea) from Spain and SW France. Cretaceous Research 28, 697-718.

Mohseni, H., Al Aasm, I.S., 2004. Tempestite deposits on a storm-influenced carbonate ramp: an example from the Pabdeh Formation (Paleogene), Zagros Basin, SW Iran. Journal of Petroleum Geology 27 (2), 163-178.

Moreno-Bedmar, J.A., Bover-Arnal, T., Barragán, R., Salas, R., 2012. Uppermost Lower Aptian transgressive records in Mexico and Spain: chronostratigraphic implications for the Tethyan sequences. Terra Nova 24, 333-338.

Moreno-Bedmar, J.A., Bulot, L., Latil, J.L., Martínez, R., Ferrer, O., Bover-Arnal, T. Salas, R., 2009a. Precisiones sobre la edad de la Fm. Escucha, mediante ammonoideos, en la subcuenca de la Salzedella, Cuenca del Maestrat (E Cordillera Ibérica). Geo-Temas 10, 1269-1272.

Moreno-Bedmar, J.A., Company, M., Barragán, R., Salas, R., Martín-Martín, J.D. Bover-Arnal, T., Gomez-Rivas, E., 2009b. Precisiones, mediante ammonoideos, sobre la edad de la Fm. Benassal, Cuenca del Maestrat (Cadena Ibérica). In Palmqvist, P., Pérez-Claros, J.A. (Eds.), Comunicaciones de las XXV Jornadas de la Sociedad Española de Paleontología, “Darwin, la Teoría de la Evolución y la Paleontología" y simposios de los proyectos PICG 493, 499 y 506, Libro de Resúmenes. Universidad de Málaga, Málaga, pp. 231-234.
Moreno-Bedmar, J.A., Company, R., Bover-Arnal, T., Salas, R., Delanoy, G. Maurrasse, FJ.-M.R. Graugés, A. Martínez, R., 2010. Lower Aptian ammonite biostratigraphy in the Maestrat Basin (Eastern Iberian Chain, Easter Spain). A Tethyan transgressive record enhanced by synrift subsidence. Geologica Acta 8 (3), 281-299.

Nebot, M., 2011. Estudi geològic d'un sector del Desert de les Palmes (Castelló de la Plana). Aplicació de cartografia digital. Undergraduate Thesis, Universitat de Barcelona, Barcelona.

Neumann, C., 1987. Le Crétacé Inférieur (Hauterivien-Albien) du Maestrazgo Meridional (Espagne): un example d'une plate-forme carbonatée en régime distensif. PhD Thesis, Université Paul Sabatier, Toulouse.

Obis, J.A., Canerot, J., Torres, T., Martínez, J.U., Moreno, E., Martínez, C., Granados, L. Schroeder, R., Pan, T., Mansialla, H., 1973. Mapa Geológico de España 1:50.000, hoja $\mathrm{n}^{\circ} 616$ (Villafamés). IGME, Madrid.

Ogg, J.G., Ogg, G., 2006. Early Cretaceous (103-138 Ma time-slice). Update to: Gradstein, F.M., Ogg, J.G., Smith, A.G., 2004. A Geologic Time Scale. Cambridge University Press, 589 pp.

Pittet, B., van Buchem, F.S.P., Hillgärtner, H., Razin, P., Grötsch, J., Droste, H., 2002. Ecological succession, palaeoenvironmental change, and depositional sequence of Barremian-Aptian shallow-water carbonates in northern Oman. Sedimentology 49, 555-581.

Pomar, L., Morsilli, M., Hallock, P., Bádenas, B., 2012. Internal waves, an underexplored source of turbulence events in the sedimentary record. Earth-Science Reviews 111, 56-81.

Reboulet, S., Rawson, P.F., Moreno-Bedmar, J.A., Aguirre-Urreta, M.B., Barragán, R. Bogomolov, Y., Company, M. González-Arreola C. Stoyanova, V. I. Lukeneder, A. Matrion, B., Mitta, V., Randrianaly, H., Vašiček, Z., Baraboshkin, E.J., Bert, D., Bersac, S., Bogdanova, T.N., Bulot, L.G., Latil, J.L., Mikhailova, I.A., Ropolo, P., Szives, O., 2011. Report on the 4th International Meeting of the IUGS Lower Cretaceous Ammonite Working Group, the "Kilian Group" (Dijon, France, 30th August 2010). Cretaceous Research 32, 786-793.

Reid, S.K., Dorobek, S.L., 1993. Sequence stratigraphy and evolution of a progradational, foreland carbonate ramp, Lower Mississippian Mission Canyon Formation and stratigraphic equivalents, Montana and Idaho. In: Loucks, R.G., Sarg. J.F. (Eds.), Carbonate sequence stratigraphy - recent developments and applications. AAPG Memoir 57, Tulsa, pp. 327-352.

Riding, R., Tomás, S., 2006. Stromatolite reef crusts, Early Cretaceous, Spain: bacterial origin of in situ-precipitated peloid microspar? Sedimentology 53, 23-34

Roca, E., Guimerà, J., 1992. The Neogene structure of the eastern Iberian margin: structural constraints on the crustal evolution of the Valencia trough (western Mediterranean). Tectonophysics 203, 203-218.

Roca, E., Guimerà, J., Salas, R., 1994. Mesozoic extensional tectonics in the southeas Iberian Chain. Geological Magazine 131, 155-168.

Salas, R. Caja, M.A., Martín-Martín, J.D., Mas, R., Permanyer, A., 2005. Mid-Late Cretaceous volcanism, metamorphism and the regional thermal event affecting the Northeastern Iberian basins (Spain). In: Arnaud-Vanneau, A., Arndt, N., Zghal, I. (Eds.), Géologie Alpine. Laboratoire de Géologie de l'Université I de Grenoble, Grenoble.

Salas, R. Casas, A., 1993. Mesozoic extensional tectonics, stratigraphy and crustal evolution during the Alpine cycle of the eastern Iberian basin. Tectonophysics $228(1-2), 33-55$

Salas, R., Guimerà, J., 1996. Rasgos estructurales principales de la cuenca cretácica inferior del Maestrazgo (Cordillera Ibérica Oriental). Geogaceta 20, 1704-1706.

Salas, J., Guimerà, J., Mas, R., Martín-Closas, A., Meléndez, A., Alonso, A., 2001. Evolution of the Mesozoic central Iberian Rift System and its Cainozoic inversion (Iberian chain). In: Ziegler, P.A., Cavazza, W., Robertson, A.H.F., CrasquinSoleau, S. (Eds.), Peri-Tethyan Memoir 6: Peri-Tethyan Rift/Wrench Basins and Passive Margins. Mém. Mus. Natn. Hist. Nat. 186, (Paris), pp. 145-185.

Salas, R., Martín-Closas, C., Querol, X., Guimerà, J., Roca, E., 1995. Evolución tectonosedimentaria de las cuencas del Maestrazgo y Aliaga-Penyagolosa durante el Cretácico Inferior. In: Salas, R., Martín-Closas, C. (Eds.), El Cretácico inferior de Nordeste de Iberia. Servei de Publicacions de la Universitat de Barcelona, Barcelona, pp. 15-47.

Salas, R., Prezbindowski, D.R., Esteban, M., 1986. The origin of Upper Jurassic-Lower Cretaceous Dolomite in Eastern Iberian Ranges (El Maestrat, Spain). XI Congreso Español de Sedimentología, Barcelona. 158.

Schlagintweit, F., Bover-Arnal, T., Salas, R., 2010. New insights into Lithocodium aggregatum Elliot 1956 and Bacinella irregularis Radoiĉić 1959 (Late JurassicLower Cretaceous): two ulvophycean green algae (?Order Ulotrichales) with heteromorphic life cycle (epilithic/euendolithic). Facies 56, 509-547.

Schmoker, J.W., Halley, R.B., 1982. Carbonate porosity versus depth: a predictable relation for south Florida. American Association of Petroleum Geologists Bulletin 66, 2561-2570.

Schroeder, R., Cherchi, A., 1981. El corte de Villarroya de los Pinares. In: Villena, J., Canerot, J. (Eds.), El Cretácico del Sector central de la Cordillera Ibérica, Field Guide. Universidad de Zaragoza, pp. 1-9.

Sclater, J.G., Christie, P.A.F., 1980. Continental stretching: an explanation of the postmid-Cretaceous subsidence of the central North Sea Basin. Journal of Geophysical Research 85, 3711-3739.

Sharp, I., Gillespie, P., Morsalnezhad, D., Taberner, C., Karpuz, R., Vergés, J., Horbury, A., Pickard, N., Garland, J., Hunt, D., 2010. Stratigraphic architecture and fracture-controlled dolomitization of the Cretaceous Khami and Bangestan groups: an outcrop case study, Zagros Mountains, Iran. In: Van Buchem, F.S.P., Gerdes, K.D., Esteban, M. (Eds.), Mesozoic and Cenozoic Carbonate Systems of the Mediterranean and the Middle East: Stratigraphic and 
Diagenetic Reference Models. Geological Society Special Publications 329, London, pp. 343-396.

Skelton, P.W., Gili, E., 2012. Rudists and carbonate platforms in the Aptian: a case study on biotic interactions with ocean chemistry and climate. Sedimentology $59,81-117$.

Spötl, C., Piman, J.K., 1998. Saddle (baroque) dolomite in carbonates and sandstones: a reappraisal of a burial-diagenetic concept. In: Morad, S. (Ed.), Carbonate cementation in sandstones. International Association of Sedimentologists Special Publication 26, pp. 437-460.

Stein, M., Arnaud-Vanneau, A., Adatte, T., Fleitmann, D., Spangenberg, J.E., Föllmi, K.B., 2012. Palaeoenvironmental and palaeoecological change on the northern Tethyan carbonate platform during the Late Barremian to earliest Aptian. Sedimentology 58, 1-25.

Strasser, A., Pittet, B., Hillgärtner, H., Pasquier, J.-B., 1999. Depositional sequences in shallow carbonate-dominated sedimentary systems: concepts for a highresolution analysis. Sedimentary Geology 128, 201-221.

Tomás, S., 2007. Sistemas arrecifales del Cretácico inferior de la Cuenca del Maestrat. Modelos deposicionales, paleontológicos y diagenéticos. PhD Thesis, Universitat de Barcelona, Barcelona.

Tomás, S., Comas, M., Salas, R., 2007. La plataforma carbonatada Aptiense superio de Benicàssim-Orpesa (Cuenca del Maestrat, Cadena Ibérica): modelo de depósito. Geogaceta 41, 235-238.

Tomás, S., Löser, H., Salas, R., 2008. Low-light and nutrient-rich coral assemblages in an Upper Aptian carbonate platform of the southern Maestrat Basin (Iberian Chain, eastern Spain). Cretaceous Research 29, 509-534.

Tritlla, J., Cardellach, E., 1997. Fluid inclusions in pre-ore minerals from the carbonate-hosted mercury deposits in the Espadán Ranges (eastern Spain). Chemical Geology 137, 91-106.
Tritlla, J., Sole, J., 1999. A newly dated Cretaceous hydrothermal event in the Iberian Ranges, (Eastern Spain) and its significance within the Mesozoic thermal history in the Iberian Peninsula. Ore Geology Reviews 15, 243-259.

Tucker, M.E., Wright, V.P., 1990. Carbonate sedimentology, second ed. Blackwell Scientific Publications, Oxford.

van Buchem, F.S.P., Gerdes, K.D., Esteban, M. (Eds.), 2010. Mesozoic and Cenozoic Carbonate Systems of the Mediterranean and the Middle East: Stratigraphic and Diagenetic Reference Models. Geological Society Special Publications 329, London.

Vilas, L., Martín-Chivelet, J., Arias, C., 2003. Integration of subsidence and sequence stratigraphic analysis in the Cretaceous carbonate platforms of the Prebetic (Jumilla-Yecla Region), Spain. Palaeogeography, Palaeoclimatology, Palaeoecology 200, 107-129.

Vilas, L., Masse, J.P., Arias, C., 1995. Orbitolina episodes in carbonate platform evolution: the early Aptian model from SE Spain. Palaeogeography, Palaeoclimatology, Palaeoecology 119, 35-45.

Warren, J., 2000. Dolomite: occurrence, evolution and economically important associations. Earth-Science Reviews 52,1-81.

Watts, A.B., 1981. The US Atlantic continental margin: subsidence history, crusta structure and thermal evolution. In: Bally, A.W., Watts, A.B., Grow, J.A. Manspeizer, W., Bernoulli, D., Schreiber, C., Hunt, J.M. (Eds.), Geology of passive continental margins: history, structure and sedimentologic record (with special emphasis on the Atlantic margin). American Association of Petroleum Geologists Education Course Note Series 19(2), Tulsa (OK).

Wilson, M.I.J., Evans, M.J., Oxtoby, N.H., Nas, D.S., Donnelly, T., Thirwall, M., 2007. Reservoir quality, textural evolution, and origin of fault-associated dolomites. American Association of Petroleum Geologists Bulletin 91 (9), 12471272 